\title{
Experimental Study on Landslides in Terraced Fields in the Chinese Loessial Region under Extreme Rainfall
}

\author{
Yongfu Wen ${ }^{1}$, Peng Gao ${ }^{2,3, *}$, Xingmin $\mathrm{Mu}^{2,3}{ }^{3}$, Mengzhen $\mathrm{Li}^{1}{ }^{1}$, Yongjun $\mathrm{Su}^{1}$ and Haixing Wang ${ }^{1}$ \\ 1 Department of Hydraulic Engineering, Hebei University of Water Resources and Electric Engineering, \\ Cangzhou 061001, China; 18706882796@163.com (Y.W.); monica_lmz@163.com (M.L.); \\ 15130800077@163.com (Y.S.); hebeishuiyuanwanghaixing@163.com (H.W.) \\ 2 State Key Laboratory of Soil Erosion and Dryland Farming on the Loess Plateau, Institute of Soil and Water \\ Conservation, Northwest A\&F University, Xianyang 712100, China; xmmu@ms.iswc.ac.cn \\ 3 State Key Laboratory of Soil Erosion and Dryland Farming on the Loess Plateau, Institute of Soil and Water \\ Conservation, Chinese Academy of Sciences and Ministry of Water Resources, Xianyang 712100, China \\ * Correspondence: gaopeng@ms.iswc.ac.cn; Tel.: +86-137-2045-8182
}

check for

updates

Citation: Wen, Y.; Gao, P.; Mu, X.; Li, M.; Su, Y.; Wang, H. Experimental Study on Landslides in Terraced Fields in the Chinese Loessial Region under Extreme Rainfall. Water 2021, 13, 270. https://doi.org/10.3390/ w13030270

Received: 17 December 2020

Accepted: 19 January 2021

Published: 22 January 2021

Publisher's Note: MDPI stays neutral with regard to jurisdictional claims in published maps and institutional affiliations.

Copyright: (c) 2021 by the authors. Licensee MDPI, Basel, Switzerland. This article is an open access article distributed under the terms and conditions of the Creative Commons Attribution (CC BY) license (https:// creativecommons.org/licenses/by/ $4.0 /)$.

\begin{abstract}
Due to the development of the scale of tractor-ploughed terraces, terraces have been increasing in number, while global climate change is causing frequent extreme rainfall events in the Loess Plateau, resulting in many terrace landslides. To study the mechanism and process of shallow landslides and deep slip surface of terraces induced by extreme rainfall in loess hill and gully area, we conducted a laboratory model test of a terrace under artificial rainfall and used the Swedish arc strip method. The research results are as follows. The mechanism of shallow landslides in terraces is rill erosion accelerating rainfall infiltration, suspending the slope, and increasing its bulk density. The destruction process of shallow landslides can be roughly divided into six processes, and the earth volume of the landslide is $0.24 \mathrm{~m}^{3}$. The mechanism of the deep sliding surface in terraces occurs under the combined action of water erosion and gravity erosion. The soil moisture content increases, which decreases the anti-sliding moment and increases the sliding moment, and the safety factor becomes less than the allowable limit for terraces. The deep sliding deformation area of the terrace was $0 \sim 1.0 \mathrm{~m}$ below the slope surface, slip surface radius was $1.43 \mathrm{~m}$, the slip surface angle was $92^{\circ}$, and the deep sliding surface began to form earlier than terraced shallow landslides. The displacement of the characteristic points increased from the slope top, to the slope center, and to the slope foot, with maximum displacements of $40.3,15.5$, and $6.0 \mathrm{~mm}$, respectively.
\end{abstract}

Keywords: laboratory model test; extreme rainfall; rill erosion; shallow landslides; deep lip surface; safety factor

\section{Introduction}

With the implementation and promotion of slope-to-terrace projects, large areas of sloping fields have been built into terraced fields [1]. The construction of terraced field projects has changed the minor features of sloping fields, reducing surface runoff and increasing soil infiltration, thus effectively improving soil moisture content, which plays a crucial role in reducing soil erosion and increasing grain yield in the surrounding areas [2,3]. However, after the implementation of slope-to-terrace projects, back-slope terraces in particular experience significantly increased rainfall infiltration, which also leads to the reduction in soil shear strength, thus increasing the risk of landslides [4,5]. For example, an extreme rainstorm event occurred in Yan'an China, which caused a large area of terraces to collapse and landslide in July 2013, as shown in Figure 1.

In recent years, due to the large-scale development of tractor-ploughed terraces, terraces have been constantly increasing in number, while global climate change has led to frequent occurrences of extreme rainfall events in the Loess Plateau, resulting in many terrace landslides [6]. Long-term production practice has proved that the outer edges 
of exposed terraces experience shallow landslides over time, which leads to the loss of its water storage and soil conservation functions [7]. When extreme rainfall produces runoff on a field's surface, the terraces seriously erode. This kind of hillslope is featured by collapsibility, strong water permeability, vulnerability, and so on, so rainfall conditions can easily induce shallow landslides, which seriously affect agricultural production [8]. As a consequence, an in-depth study of the process and mechanisms of shallow landslides and deep slip surface of terraces under extreme rainfall is theoretically significant for disaster prevention and mitigation and has practical value for agricultural production in Northern Shaanxi [9-13].
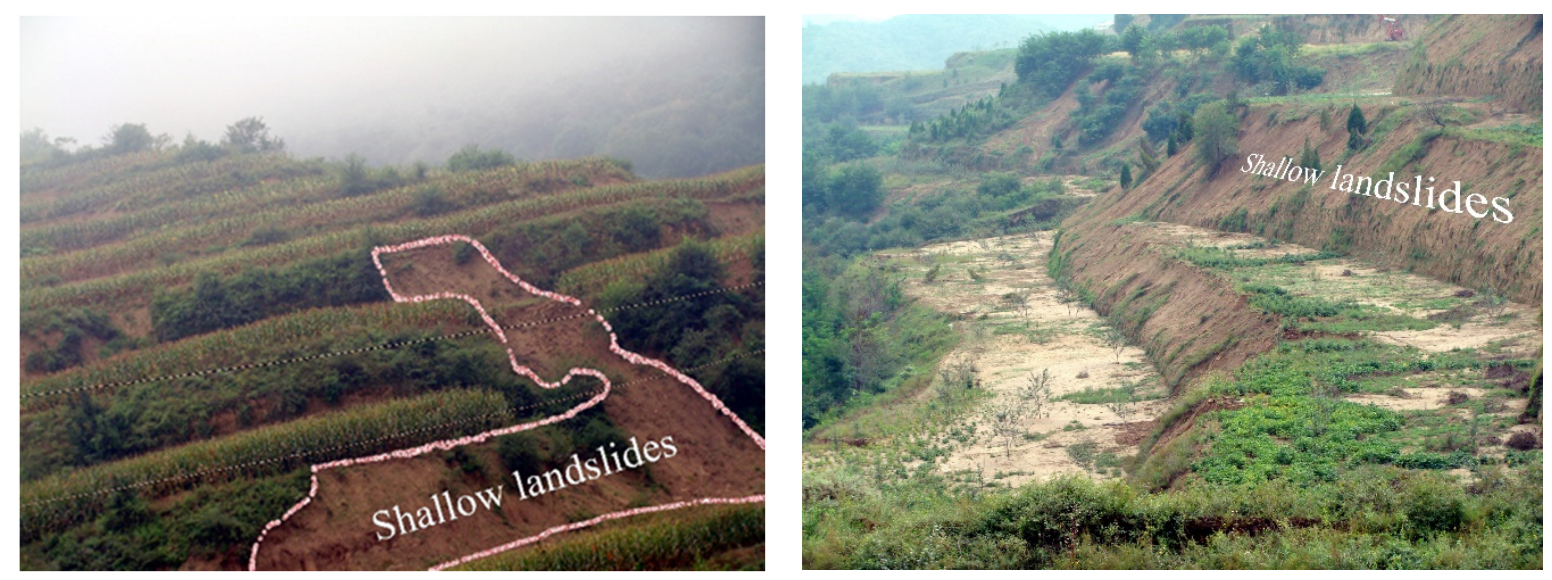

Figure 1. Shallow landslides of terraces in Yan'an China, in July 2013.

Research on the mechanisms of the rainfall-induced general slope instability of soil, rock, and soil-rock mixture has mainly focused on field measurements, numerical simulations and model tests [14-17]. The model test has favorable intuition and can comprehensively consider various factors, simulate complex boundary conditions, and reflect the deep interaction of landslides under the condition of basically meeting the similarity principle [18]. Using the model test of soil slope instability induced by rainfall, Lin et al. [19] discussed the influence of the characteristics of precipitation on slope instability, and thereby selecting appropriate rainfall warning parameters. Zuo et al. [20] studied the laws of seepage, deformation, damage, and particle migration of accumulating soil slope under rainfall conditions through a rain-triggered landslide model test of accumulation bodies with different gradations; they also discussed the influence of particle size on the stability of accumulation soil slope. Li et al. [21] constructed an artificial rainfall simulation test of slopes with different angles and studied the changing laws of the front-end thrust, moisture content and deformation of the slope. Jeong et al. [22] comprehensively analyzed landslides caused by rainfall through laboratory tests, field tests and numerical analysis. Their results showed that landslide activity is closely related primarily to rainfall, soil properties, slope geometry, and vegetation. Numerical analysis was also performed to confirm the effect of these factors on landslide occurrence. Aleotti [23] identified the empirical triggering thresholds for Piedmont and proposed an NI-NCR (where NI is normalized intensity with respect to the annual precipitation, where NCR is the normalized cumulative critical rainfall) diagram. Xu et al. [24], Wang et al. [25], Tohari et al. [26], and Huang et al. [27] conducted rainfall landslide model tests and study the influence of compactness, silt particle content, water level, and other factors on pore water pressure, water content, landslide start-up and development, and failure mode.

The above studies considered the deformation of slope under the condition of rainfall infiltration-seepage interaction, which is mainly concentrated on engineered and natural slopes in China [28,29]. Current research on terraces has mostly focused on the benefits of water and sediment reduction and the rill erosion of terraces [30-33]. However, research on rainfall-induced shallow landslides of terraces is still lacking in China. A number of 
studies have performed some advantageous explorations. For instance, Jiang [34] discussed the design of terrace sections in the Loess Plateau by considering the requirements for small construction quantity, less land loss, good stability, convenience for cultivation, and conduciveness for crop growth of the terrace ridge. Given the problem of the steep or slow ridges in terrace construction in the sandy, mountainous area of Linqu County, Ge [35] analyzed the stability of the ridge shear test, and the results showed that the slope angle of fine gravel sand ought to be $37^{\circ}$, and that of fine sand should be $34^{\circ}$. Zhang et al. [36] used the Green-Ampt model to study the slope stability of terraced fields based on crop irrigation infiltration and discussed the position of the potential sliding surface. Yang et al. [37] selected the terraced ridge in Southern Shaanxi province as the research object and explored the failure forms and causes of the ridge through an indoor conventional triaxial shear test. Liu [38] studied the changes in the failure time and safety factor of a horizontal terrace, a separated slope terrace and an original slope (for contrast) under a rainfall infiltration intensity of $28 \sim 38 \mathrm{~mm} / \mathrm{h}$ and a side slope gradient of 15-30 using ABAQUS software. Derbyshire [39] discusses how terraces in the Loess Plateau can maintain good stability under a natural state, but tend to be eroded and collapse under rainfall infiltration.

In this study, we selected terraces as the research object, and indoor model tests and the Swedish arc strip method were used to study the mechanism and mode of shallow landslides and deep sliding surfaces in terraces under extreme rainfall conditions. The following assumptions were made for the test. We ignore the influence of: (1) the model's side wall on the test results; (2) the internal sensors on the test results; and (3) the soil disturbance on the test results. The research is important for the agricultural development of the loess hilly and gully region as it provides: (1) a reliable theoretical basis and abundant experimental data for slope collapse and instability prevention, and disaster mitigation, monitoring, and forecasting of terraces; (2) parameters for the optimized design of terraces; and (3) a method for studying multi-level terraces and terraced landslides in the basin.

\section{Materials and Methods}

\subsection{Test Soil Properties}

The soil used in this model test was obtained from Zhifanggou, Ansai County, Shaanxi province, China; the depth of sediment deposition is $6 \sim 8 \mathrm{~m}$, so it belongs to the category of loessal deposits [40]. The basic parameters of the test soil are shown in Table 1. According to the light compaction test, the maximum dry bulk was $1.703 \mathrm{~g} / \mathrm{cm}^{3}$ and the optimal moisture content was 19.3\%. The particle size of the soil was measured by a Marven laser hondrometer, with a measured range of $0 \sim 2 \mathrm{~mm}$, and the characteristic values of average grading in the Table 1 are as follows: clay particle $(\leq 0.002 \mathrm{~mm})$ content was $12.1 \%$, silt particle $(0.05-0.002 \mathrm{~mm})$ content was $52.6 \%$, and sand $(2-0.05 \mathrm{~mm})$ content was $35.4 \%$, which showed that the soil sample contained fewer particle size series and that the difference between coarse and fine particle sizes was small. The curvature coefficient (CC) of the particle grading curve was 1.79 , which is well-graded.

Table 1. Basic property indexes of soil.

\begin{tabular}{cccccc}
\hline Great Group & $\begin{array}{c}\text { Natural } \\
\text { Density } \\
(\mathbf{g . c m}\end{array}$ & $\begin{array}{c}\text { Natural } \\
\text { Water } \\
\text { Content }(\%)\end{array}$ & $\begin{array}{c}\text { Dry Density } \\
\left(\mathbf{g} . \mathrm{cm}^{-3}\right)\end{array}$ & $\begin{array}{c}\text { Cohesion } \\
\mathbf{( K p a )}\end{array}$ & $\begin{array}{c}\text { Internal } \\
\text { Friction } \\
\text { Angle }\left(^{\circ}\right)\end{array}$ \\
\hline $\begin{array}{c}\text { Calcic } \\
\text { Cambisols }\end{array}$ & 1.32 & 7.86 & 1.21 & 13.85 & 20.10 \\
\hline
\end{tabular}

\subsection{Test Device}

The test equipment was divided into four major systems: test object, rain, data monitoring, and image capture systems (Figure 2). 


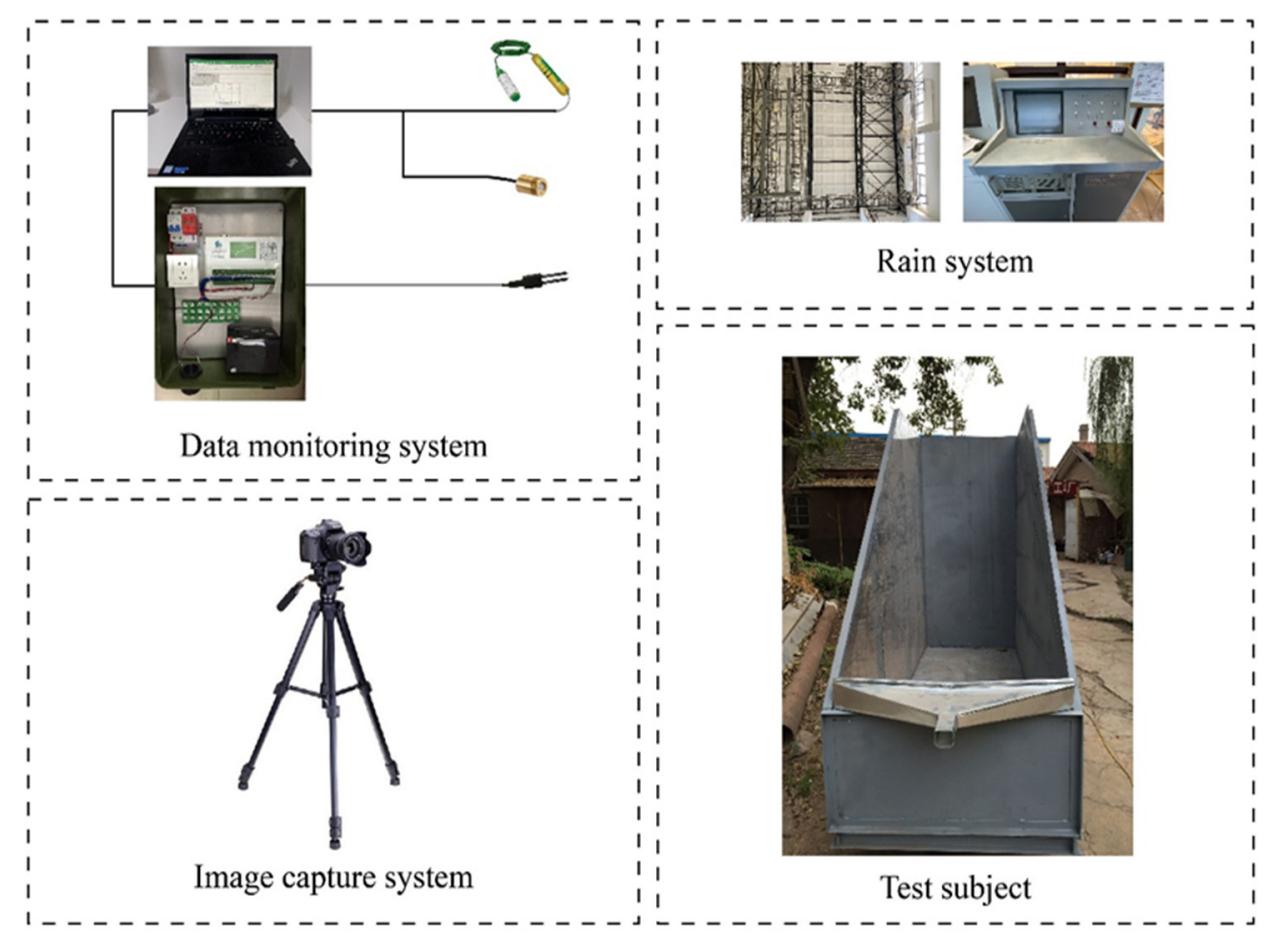

Figure 2. Schematic diagram of model test device.

The test object system involved a terrace groove with a length of $2.8 \mathrm{~m}$, a width of $1 \mathrm{~m}$ and a height of $2.1 \mathrm{~m}$. The height of the slope filled in the test was $1.2 \mathrm{~m}$, with a gradient of $65^{\circ}$. The front and back edges and one side of the model were surrounded by steel plates, and the wall surface of which was smoothed by applying a layer of Vaseline to reduce the influence of the model boundary effect on the test. On the remaining side, transparent plexiglass with a thickness of $1 \mathrm{~cm}$ was used as a visual window to help observe the movement of soil at any time in the process of the test. To facilitate the observation of soil movement, a rectangular grid measuring $10 \times 20 \mathrm{~cm}$ was drawn onto the transparent poly, and steps were placed close to the steel plate to facilitate the measurement of the channel shape parameters and flow velocity during the test. A catch basin was set up at the front edge to collect runoff sediment.

The rain system device was developed by the Institute of Soil and Water Conservation, Ministry of Water Resources, Chinese Academy of Sciences. The rainfall device's height is $16 \mathrm{~m}$, which can measure the terminal speed of all raindrops. The range of rainfall intensity was $40-260 \mathrm{~mm} / \mathrm{h}$, the rainfall uniformity was more than $80 \%$ and the maximum duration of rainfall was $12 \mathrm{~h}$. The rainfall area was composed of two independent rainfall experimental areas. The effective rainfall area of a single experimental area was $4 \times 9 \mathrm{~m}$, which can accurately simulate natural rainfall [41].

The data monitoring system was composed of a RR-7120 water content sensor, KPE$200 \mathrm{kPa}$ pore water pressure sensor, Campbell 257 soil suction sensor, and an LDS-S-200 displacement monitoring sensor. Each sensor was connected to the corresponding collection system through a data line, and then the data in the system is exported and sorted through a computer. The data collection frequency of the water content sensor was $1 \mathrm{~min}$, (unit: \%); the data collection frequency of the pore water pressure sensor was 1 min (unit: Ka); the acquisition frequency of the suction sensor data acquisition system was $1 \mathrm{~min}$ (unit: Ka); the displacement monitoring sensor data acquisition system had an acquisition frequency of $1 \mathrm{~min}$ (unit: $\mathrm{mm}$ ).

For the image capture system, a Canon EOS M50 camera was set up on the side facing the transparent plexiglass at a height of $0.85 \mathrm{~m}$, to clearly capture the downward movement of the wet front on the side of the soil. 


\subsection{Soil-Filling and Sensor Embedding}

A square sift iron was applied for screening to ensure the maximum particle size of the model's soil filling would be less than $1 \mathrm{~cm}$. Then, the soil was evenly spread, sprayed with an appropriate amount of water and evenly mixed to make the density and moisture content of the soil close to that of the undisturbed soil. However, in the process of model filling, the structure of the soil, the particle gradation, the stratum structure, the soil cracks, and so on, will change to some extent, which is inevitable. For this test, we adopted the method of layered compaction and filling: the soil prepared before the test was evenly divided into 17 layers, each layer $10 \mathrm{~cm}$ thick, and the side wall of the terrace was compacted with a discus. After the compaction of each layer was completed, samples were taken from several different parts with a cutting ring. The wet density of each layer of soil was $1.32 \sim 1.40 \mathrm{~g} / \mathrm{cm}^{3}$, and the moisture content was around $7.5 \%$. After the placement into layers was complete, the geometric dimensions of a $65^{\circ}$ slope in the model was obtained by manual slope cutting after the stratified filling.

To ensure the accuracy of the monitoring data and minimize the impact of sensors on the test results, we arranged the fewest sensors possible. Figure 3a provides a crosssectional view of terraced soil filling and sensor embedding, showing that two moisture content sensors were arranged on the side close to the slope every $20 \mathrm{~cm}$. Due to the large soil width, one more was arranged on the bottom side, for a total of 13 sensors. To study the mechanical properties of the slope, three pore water pressure sensors and suction sensors were arranged on the top, middle and toe of the slope with a vertical distance of $20 \mathrm{~cm}$ from the slope surface. To accurately determine the shape of the slip surface, 5 to 7 displacement sensors were arranged every $20 \mathrm{~cm}$, for a total of 36 displacement sensors. To reduce the influence of the sensor on the test results, the sensor was arranged in the middle of the whole soil, as shown in Figure 3b.

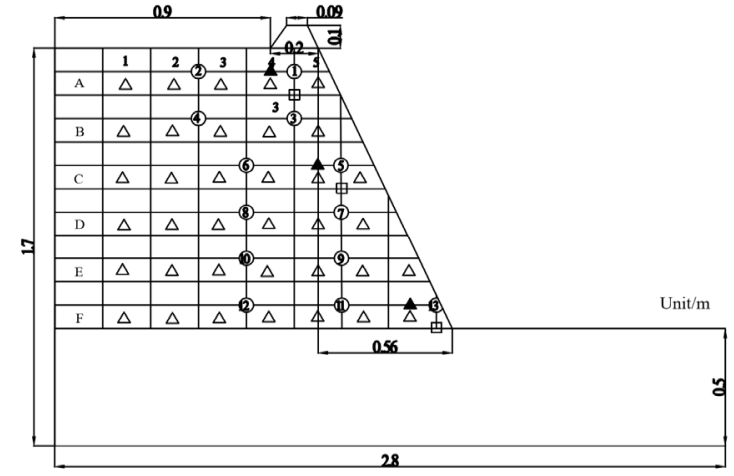

(a)

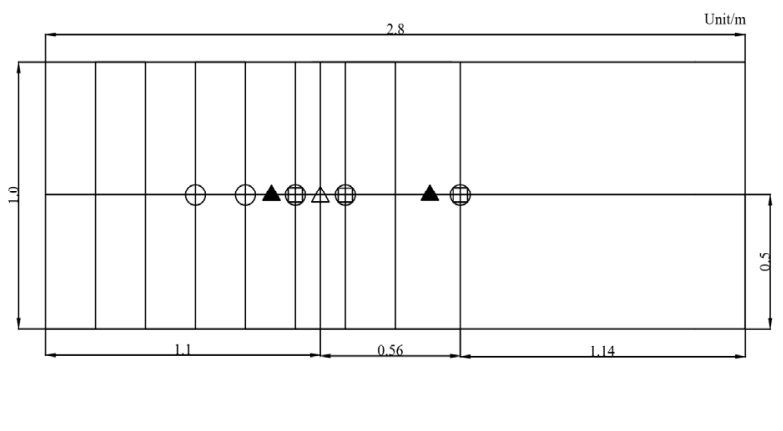

(b)

Figure 3. Layout drawing of test sensors. (a) Left view of device, (b) top view of device. Note: Different letters indicate soil layers; Numbers indicate soil columns; $\bigcirc$ indicates soil water content sensor; $\square$ indicates pore water pressure sensor; $\triangle$ indicates monitor point of displacement; $\boldsymbol{\Delta}$ indicates soil water suction sensor.

\subsection{Test Method}

The experiment started at 10:00 a.m. on 11 November 2017 and ended at 8:00 a.m. on the 12 November. It was carried out in Area II of the artificial rainfall hall of the Institute of Soil and Water Conservation, Ministry of Water Resources, Chinese Academy of Sciences. According to the hydrological data for Yan'an in July 2013, and the actual situation of slope movement, the data were divided into five periods of rainfall, each lasting for 1 hour, with rainfall intervals of $1 \mathrm{~h}$, a rainfall intensity of $2.5 \mathrm{~mm} / \mathrm{min}$ and a total rainfall of $750 \mathrm{~mm}$. The test was repeated once on 20 November 2017, and the average of the data from the two tests was used as the test result for analysis, and the standard deviation of each dataset was found to be within 0.2 , so the data were considered reasonable and reliable. 
To ensure the uniformity and stability of the rain intensity, the slope of the terraces was covered with plastic sheeting before the test. The rain intensity was calibrated around the model trough and the top. When the rain intensity stabilized, we quickly uncovered the plastic sheet and started timing. When the water flow on the slope of the terraces was in a laminar flow state and flowed from top to bottom to the water outlet, it was regarded as the start of runoff. We recorded the runoff time, and then restarted the clock. After the trial runoff, runoff and sediment samples were collected every $1 \mathrm{~min}$. After rills appeared on the slope, the time of rill appearance was recorded, and we measured the size with a measuring tape with an accuracy of $1 \mathrm{~mm}$ every $2 \mathrm{~min}$. When the rill length exceeded $10 \mathrm{~cm}$, we measured the width every $10 \mathrm{~cm}$ along the length of the rill. The average value was used as the width of the rill. The measurement density was increased in locations where the morphological mutation of the rill was obvious. Simultaneously the slope and wet front morphology were recorded every $20 \mathrm{~min}$ with a digital camera, and the camera shooting frequency was increased during the period of severe morphological changes. After the test was over, the sediment samples were allowed to stand for $6 \mathrm{~h}$ and the supernatant liquid was poured out, then the sediment samples were dried in an oven $\left(105^{\circ}\right)$ and weighed by electronic scale. The sensor data were imported into an Excel table for data preprocessing.

When calculating the moisture content data, the sensor data at the same time point of each layer were averaged, and this average value was regarded as the soil moisture content of this layer. Because the data collection frequency was very fast, a large amount of data were generated. Therefore, we selected the representative data to draw figures under the premise of not affecting the changing of the parameter curve.

\section{Results and Discussion}

\subsection{Mechanism and Process of Shallow Landslides of Terraces \\ 3.1.1. Mechanism of Shallow Landslides of Terraces}

The results suggest that the shallow landslides of terraces were caused by rill erosion. Most of the rills in the loessial soil were developed by a single drop sill, which was mainly manifested by the headway erosion of the gully head and the collapse of the side wall [42,43] (Figure 4a). By measuring the traceable erosion pattern of terraces, we found that the maximum width of the gully head was $34.25 \mathrm{~cm}$, the maximum depth was $21.32 \mathrm{~cm}$, and the maximum length was $75.86 \mathrm{~cm}$. The total erosion amount was about $270.96 \mathrm{~kg}$. The sediment yield rate of five rainfalls was 181, 475.67, 1707.17, 1624.33, and 527.83 g/min. The sediment yield rate showed a trend of increasing first and then decreasing. Before the runoff, when the exposed slope surface was hit by large raindrops, the surface soil structure was destroyed, and the soil particles splashed up and fell back to the slope surface, forming raindrop splash erosion (Figure 4b). After the runoff, the erosion developed from raindrop splash erosion to layered surface erosion. The time from splash erosion to surface erosion was one hour (Figure 4c). The reason for this finding is that the runoff was low at the initial stage of runoff generation and the runoff eroding force was less than the anti-erosion ability of soil resistance. With the increasing runoff, runoff eroding force also increased. Isolated and sporadic falling ridges were generated in the terrace ridge and the vulnerable parts of the side slope's soil. When the terrace ridge was filled with water, the terrace ridge breached under the action of hydraulic erosion (Figure $4 \mathrm{~d}$ ) and the water cut down along the breach to form obvious gullies, with an average width of $17.8 \mathrm{~cm}$ (Figure $4 \mathrm{e}$ ). Due to the erosion, transportation, and accumulation of overtopping flow, the erosion gully continuously eroded and undercut longitudinally, eroding the gully bank and widening the gravity collapse horizontally. The sediment carried by the slope flow was fan-shaped deposition around the gully mouth at the toe of the slope, forming an alluvial fan, covering an area of $176.64 \mathrm{~cm}^{2}$ (Figure $4 \mathrm{f}$ ). The erosion gully further developed and constantly degraded and widened. Due to the difference in the density of terraces and the non-uniformity of the filling materials, the velocities of anti-erosion of the terraces differed. The weak position started easily, and erosion occurred first, forming a scouring pit. 


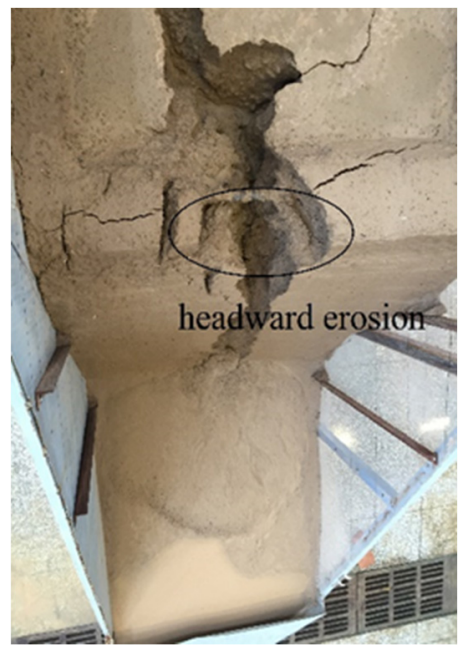

(a)

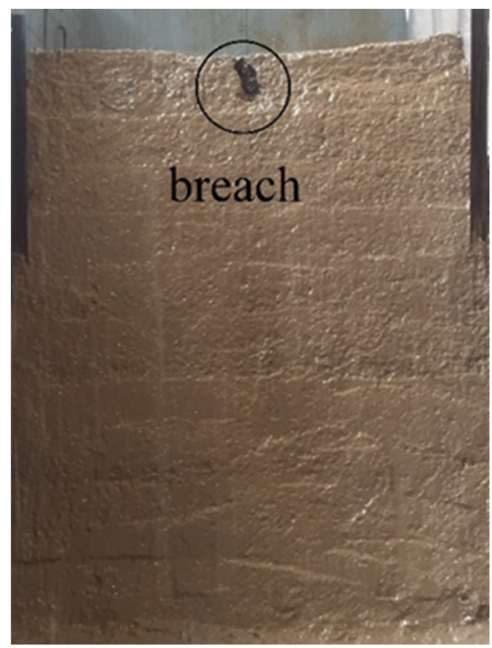

(d)

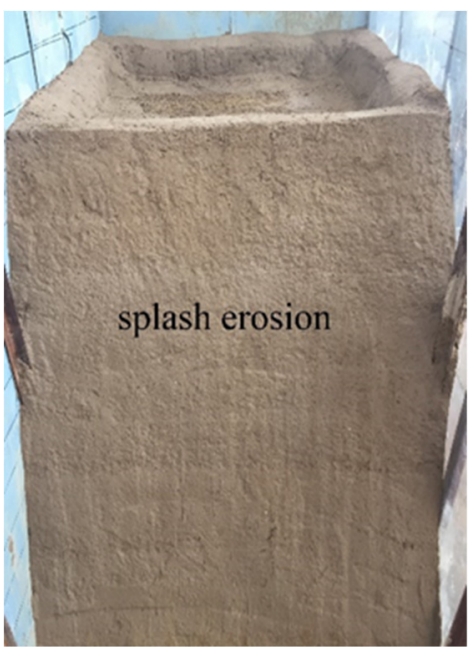

(b)

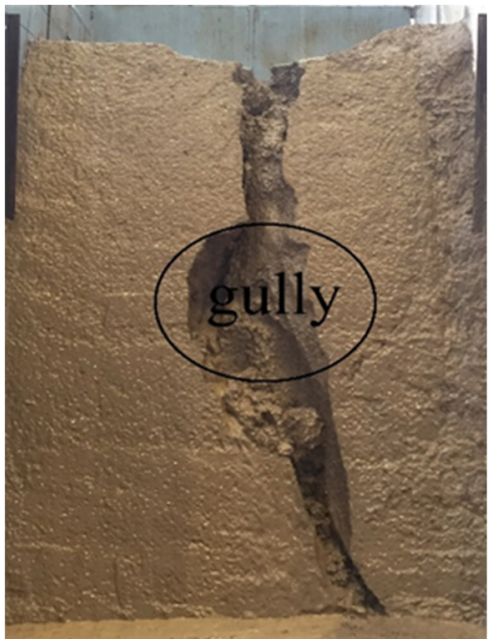

(e)

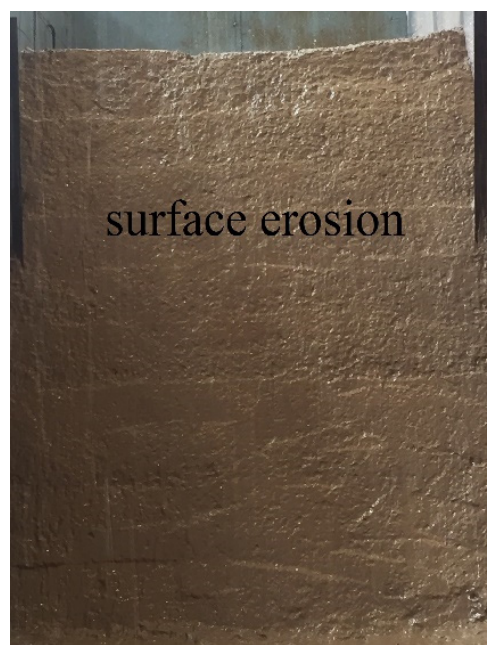

(c)

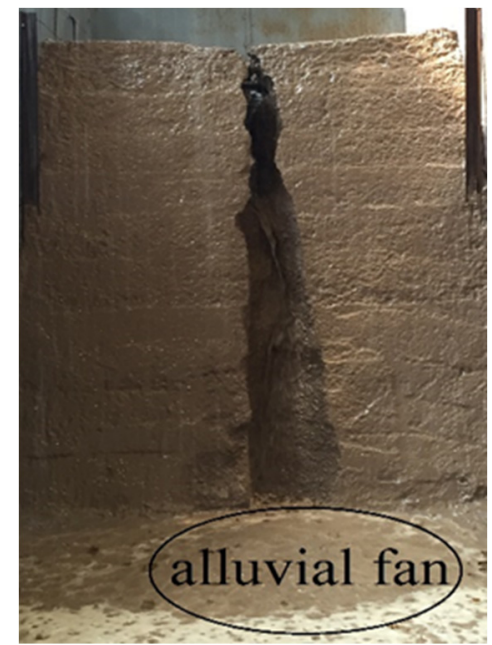

(f)

Figure 4. Morphological characteristics of terraces at different rainfall times; (a) Headward erosion, (b) Splash erosion, (c) Surface erosion, (d) Breach, (e) Gully, (f) Alluvial fan.

The above characteristics all indicate that many side wall collapses occur in the process of rill formation, which is consistent with the phenomenon observed in the test process. It is generally thought that the composition of soil particles is an important factor affecting soil erosion resistance. The finer the particle composition, the stronger the cohesion. To a certain extent, when the soil forms a mass structure, and its anti-erosion ability will be higher. In particular, the clay content in the soil significantly enhances the anti-dispersion ability of the wet soil layer. It can be seen from Table 1 shows that silt $(0.002 \sim 0.2 \mathrm{~mm})$ and clay $(<0.002 \mathrm{~mm})$ only accounted for around $35 \%$ of the total particles in the model. The overall stability of the soil was poor. In addition, the content of sand particles was high, and the soil was loose and porous. Therefore, the rill side wall of the loessal soil easily lost stability and collapsed under the action of runoff erosion and soil moisture. As such, the main forms of the rill development process of loessal soil are wall collapse and traceable erosion, and the randomness is significant [44]. Han et al. [45] and Acharya et al. [46] also showed that traceable erosion is the most active sediment yield factor in rill development, and the collapse of the ditch wall mainly occurred on steep slopes above $65^{\circ}$. Both the rill and cut trench in this experiment were similar in shape to the above research results, but 
the size was larger, because the rainfall intensity and total rainfall were higher than in the above experimental conditions.

\subsubsection{Process and Mode of Shallow Landslides of the Terraces}

According to a series of deformation characteristics of the side slope during the test, the mode of this kind of shallow landslide of terraces under rainfall conditions is summarized in this section. The deformation mode is shown in Figures 5 and 6 and can be described as follows: (i) The stage of water accumulation on terraced fields: As the rainfall continued, the soil of the terraces gradually became saturated, which reduced the infiltration capacity of the soil, while the rainfall gradually increased, resulting in water accumulated on the terraces. The height of stagnant water was $3.5 \mathrm{~cm}$. (ii) The formation and development stage of the breach: After rainfall had been occurring for a period of time, the loess on the terrace surface and its slope surface reached saturation. The ponding on the field surface crossed the ridge, forming surface runoff and flowing down the slope. When the water flows through the ridge, the erosion of the ridge formed a breach with area of $706 \mathrm{~cm}^{2}$. With the continuous erosion of water and rainfall, the erosion degree of the ridge increased and the breach expanded. (iii) The erosion of the waterfall nappe flow: The ponding flowed along the breach and formed plumes. Under the combined action of hydraulic forces and gravity, the discharge flow formed a multi-stage drop sill on the slope surface. The maximum discharge and maximum velocity of the breach occurred at this stage, and the ponding on the terrace surface dropped rapidly. (iv) The formation and development stage of the erosion gully: With continuous rainfall, the multi-level drop sill was connected by the water flow, forming an erosion ditch, and the width and depth of the erosion ditch gradually increased along the slope shoulder to the slope toe, finally forming the alluvial fan at the slope toe. The average erosion gully width was $17.8 \mathrm{~cm}$. (v) The stage of superficial-layer shallow landslides of the terraces: With increases in the width and depth of the erosion gully, the soil on both sides of the slope was suspended. In addition, the soil is constantly saturated with water, the gravity increased and the cohesion decreased, resulting in superficial-layer shallow landslides of the terraces, and the soil volume of the landslide was about $0.24 \mathrm{~m}^{3}$ (vi) The terraces tend to be stable: After the superficial-layer shallow landslides of the terraces, the side slope grade of the residual slope was very small; even if the soil was in a saturated state, it would not easily collapse.

The pattern of shallow landslides in terraces is similar to that in the earth dams. Zhong et al. [47] used experimental methods to simulate the mechanism and mode of earth dam failure, they proposed that the most important reasons for earth dam failure are the overflow of water, the crest of the dam breaking, and the huge instantaneous downflow washing the earth dam. The dam break test (dam height $6 \mathrm{~m}$ ) funded by the EU IMPACT project [48] and the dam break test (dam height 1.5 to $2.3 \mathrm{~m}$ ) carried out by Hanson et al. [49] of the United States Department of Agriculture both simulated the earth dam break mode, which is similar to the landslide pattern of the terraces, but the mechanism is different. The dam break mechanism of action of an earth dam is through the upstream water flow forming an infiltration line inside the dam body due to the seepage effect, or the upstream water flowing over the top to destroy the earth dam. The terrace landslides mechanism is through the soil losing cohesion due to rainfall infiltration and the erosion ditch making the terraces lose their integrity, leading to local shallow landslides. The results of this study are different from those of Sun et al. [50] because there is a border dike on the loess slope in the natural state. When the rainfall intensity is greater than the infiltration rate, the slope will produce runoff. For terraced fields, the border dike plays a role in water storage and soil conservation. Therefore, under the same rainfall conditions, terraces are more capable of resisting catastrophic rainfall than sloping fields. 


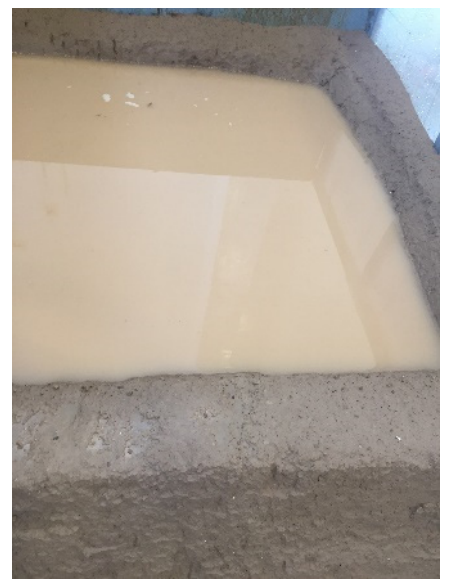

(a)

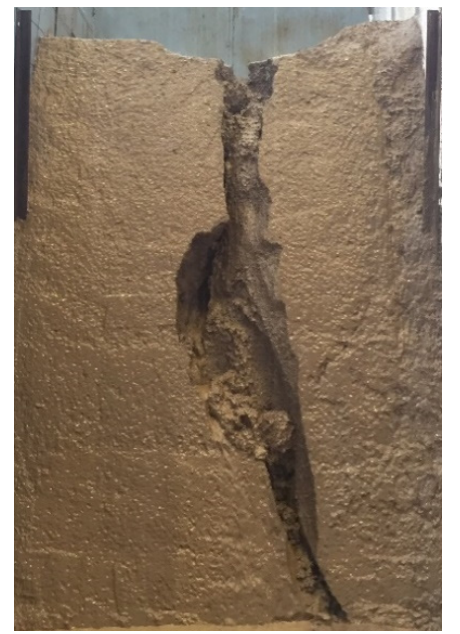

(d)

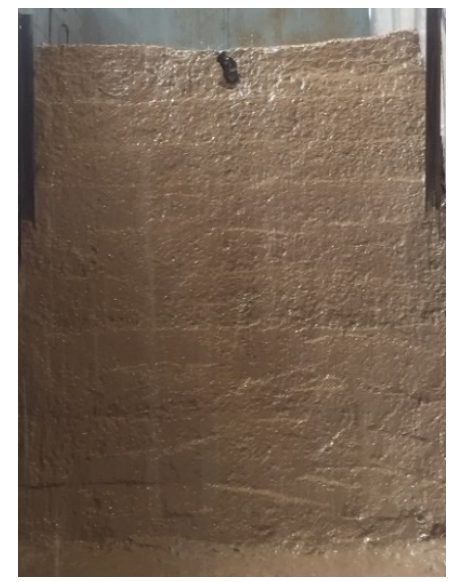

(b)

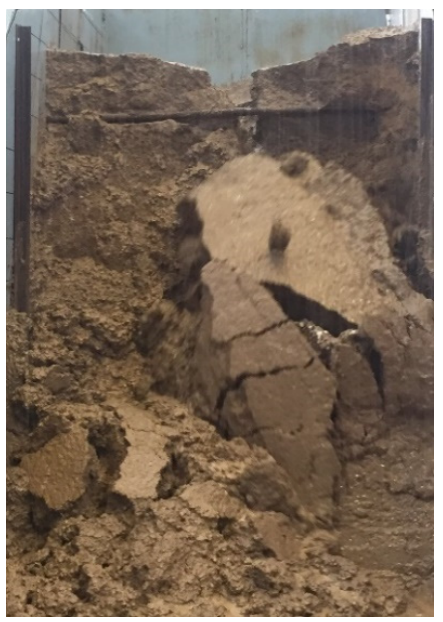

(e)

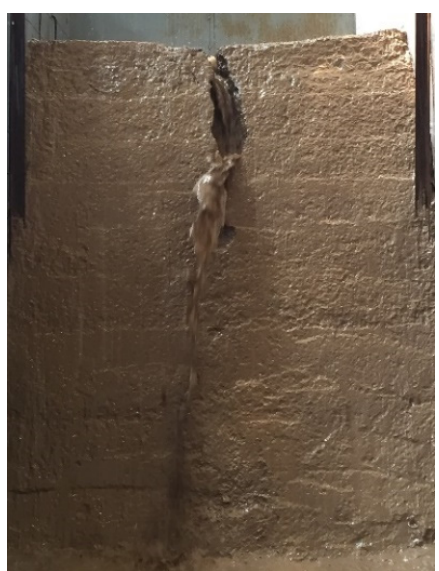

(c)

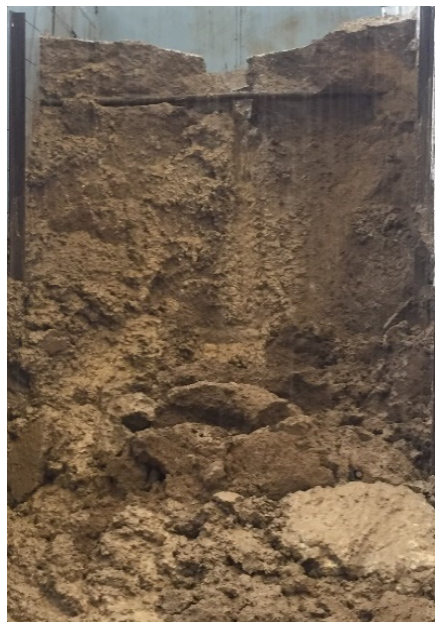

(f)

Figure 5. Shallow landslide process in terraces. (a) First stage, (b) Second stage, (c) Third stage, (d) Fourth stage, (e) Fifth stage, (f) Sixth stage.

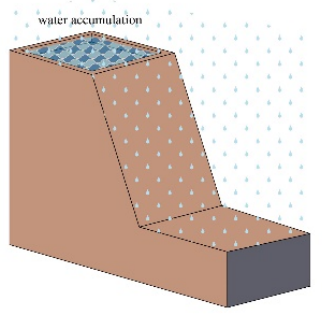

(a)

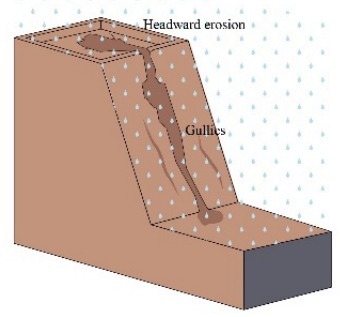

(d)

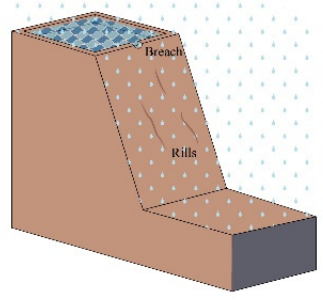

(b)

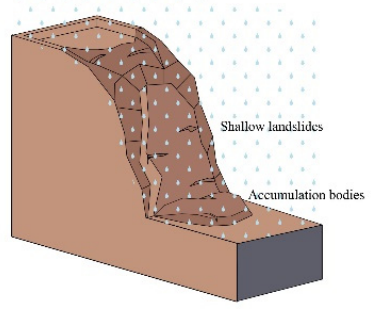

(e)

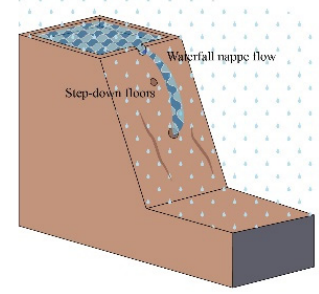

(c)

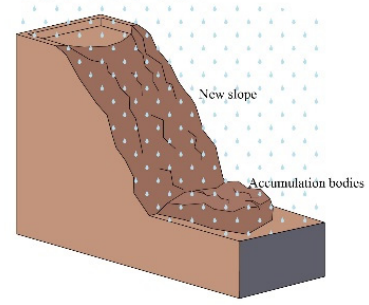

(f)

Figure 6. Three-dimensional diagram of shallow landslide process in terraces. (a) First stage, (b) Second stage, (c) Third stage, (d) Fourth stage, (e) Fifth stage, (f) Sixth stage. 


\subsection{The Factors of Deep Slip Surface of Terraces}

\subsubsection{Rainfall Infiltration}

The curve in Figure 7 shows the relationship between average rainfall (infiltration), infiltration percentage, and rainfall frequency. The infiltration rate was $79 \%$, and the infiltration rate gradually decreased with the increase in surface runoff. In the third rainfall event, the infiltration rate decreased to $49.3 \%$ and then remained steady at approximately $26.14 \%$. More than half of the rainfall turned into surface runoff, causing soil erosion and rain erosion on the slope's surface and formed rills. The infiltration of rainwater from the slope surface to the slope was an unsaturated-to-saturated seepage process, and the change in infiltration rate with time was related not only to the original humidity and matrix suction of unsaturated soil, but also to the physical characteristics and structure of the soil from the side slope. Generally, at the early stage of infiltration, infiltration capacity is greater than rainfall intensity and the infiltration rate is higher, so infiltration is pressureless. After a period of time, the soil begins to saturate, the gradient of soil moisture content decreases, the matrix suction reduces, and the infiltration capacity lowers. When rainfall intensity is greater than the soil's infiltration capacity, slope runoff occurs, which is pressure infiltration. Finally, with rainfall, the infiltration rate gradually decreases until it tends to be constant, reaching the stable infiltration stage. Figure 8a shows the relationship curve between infiltration rate and rainfall time for five rainfall events, and Figure $8 \mathrm{~b}$ provides partial enlarged view; the figure shows, the infiltration rate generally presents the same decreasing trend. The steady infiltration rate ranged from $0.74 \mathrm{~mm} / \mathrm{min}$ to $0.77 \mathrm{~mm} / \mathrm{min}$, and the results are similar to those in the literature [51]. This is because with progressing rainfall, the infiltrating rainwater continuously increased the soil moisture content, which saturated the surface soil causing the infiltration rate to gradually decrease. However, the infiltration rate of the topsoil was relatively low and stable after saturation, and the infiltration rate of rainwater was further reduced due to the small amount of rainwater infiltration inside. For the third and fourth rainfall events, the infiltration rate first increased and then decreased. The reason for the increase in the third rainfall's infiltration rate was that cracks appeared on the terrace surface and the infiltrated rainwater could speedily travel deep through the cracks; on the other hand, due to the water-retaining effect of the ridge, ponding formed on the horizontal surface, which accelerated the infiltration rate. The reason for the increase in the infiltration rate in the fourth rainfall was that the superficial layer of the terrace collapsed and the rainwater rapidly entered into the soil along the gully.

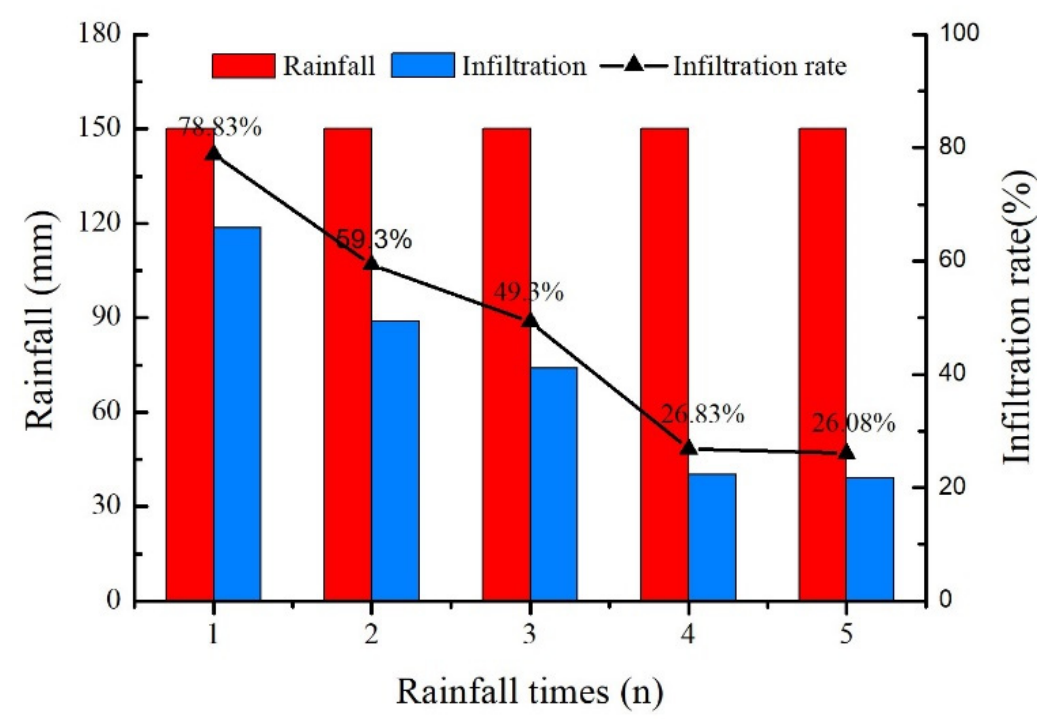

Figure 7. Rainfall amounts and percentage of infiltration. 


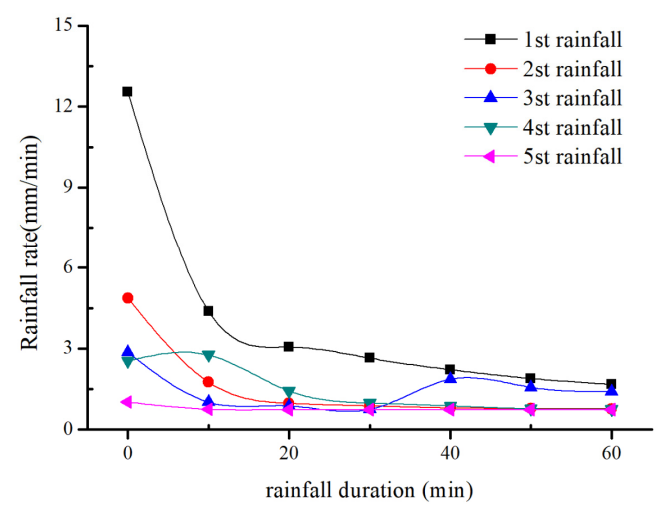

(a)

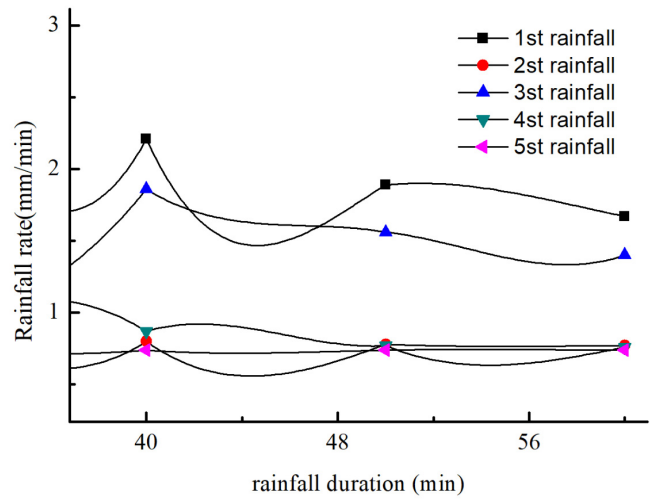

(b)

Figure 8. Relationship between infiltration rate and rainfall time in five rainfalls; (a) The relationship curve between infiltration rate and rainfall time for five rainfall events, (b) partial enlarged view of the Figure 8a.

In this study, the rainfall infiltration law of terraces is similar to that of Liu et al. [52], but the infiltration rate is lower than the latter, because Liu et al. considered the development characteristics of the root system in vegetation and soil, which has strong water storage and soil conservation capabilities and can intercept more rainfall and runoff. Compared with Huang et al. [53], the infiltration rate of this result is relatively high because of the different nature of the soil. The initial moisture content of the soil in Huang et al.'s research was high, and the initial moisture content will shorten the saturation time of the soil. The results of this test provide reference value for the study of terrace infiltration in loess hilly and gully areas, especially for mechanically-repaired horizontal terraces.

With the continuous infiltration of rainwater, the color of the soil from the model's side slope gradually darkened with the increase of in moisture content, and the infiltration peak appeared at the boundary between the dark- and light-colored soils. In this test, the change in infiltration peak was recorded by a camera set up on the side of the transparent poly to judge and calculate the infiltration depth and infiltration rate of rainwater.

Figure 9 depicts the wetting front from different rainfall time points: when the rainfall duration was $10 \mathrm{~min}$, the downward depth of the wet front was $9.7 \mathrm{~cm}$; when the rainfall duration was $60 \mathrm{~min}$, the downward depth of the wet front was $28.8 \mathrm{~cm}$; and when the rainfall duration was $180 \mathrm{~min}$, the downward depth of the wet front was $35.5 \mathrm{~cm}$. The wet front was basically linear with the rainfall time. The wetting front moved downward with increasing duration of rainfall and the migration rate of the horizontal wetting front was faster than that of the side slope surface. The reason for this finding is that the horizontal plane could effectively intercepted the rainwater, and the ponding accelerated the infiltration rate of the horizontal surface [54]. However, for the inclined slope, most of the rainwater formed runoff along the side slope surface, and only a small part of the rainwater infiltrated. Figure 10 shows that with continuous rainfall, a proportion of the rainwater on the terrace surface infiltrated, another part formed slope runoff, and some of it infiltrated along the back wall of the model box, where collapse deformation occurred. Due to the different materials of the back wall and the soil, the infiltration speed was faster than that of the soil; thus, the wetting front moved rapidly in the back wall. 


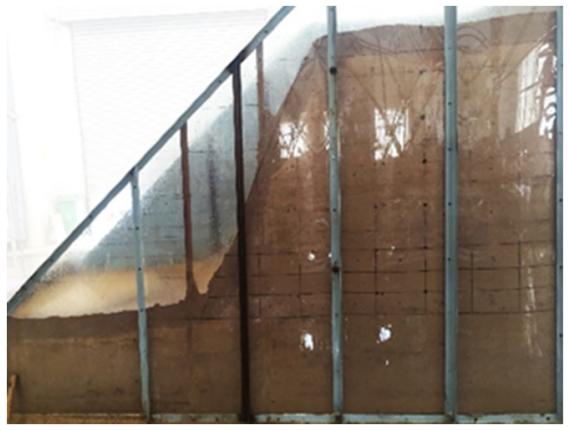

(a)

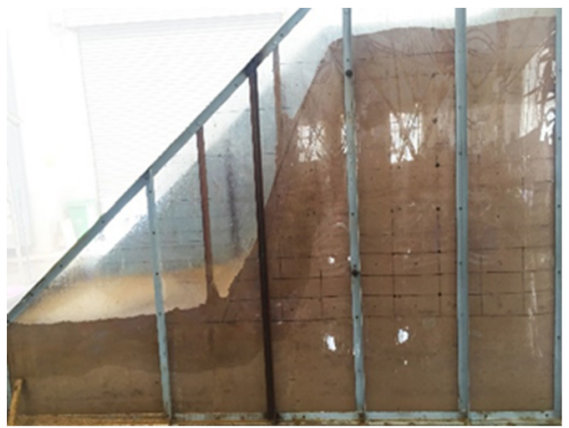

(c)

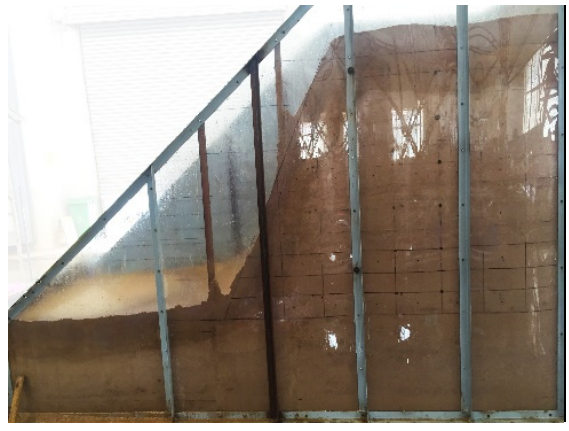

(b)

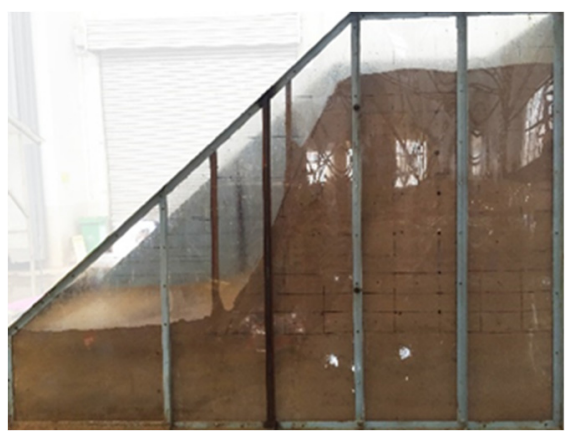

(d)

Figure 9. Infiltration peaks at different rainfall time; (a) $\mathrm{T}=10 \mathrm{~min},(\mathrm{~b}) \mathrm{T}=60 \mathrm{~min},(\mathbf{c}) \mathrm{T}=180 \mathrm{~min}$, (d) $\mathrm{T}=300 \mathrm{~min}$.

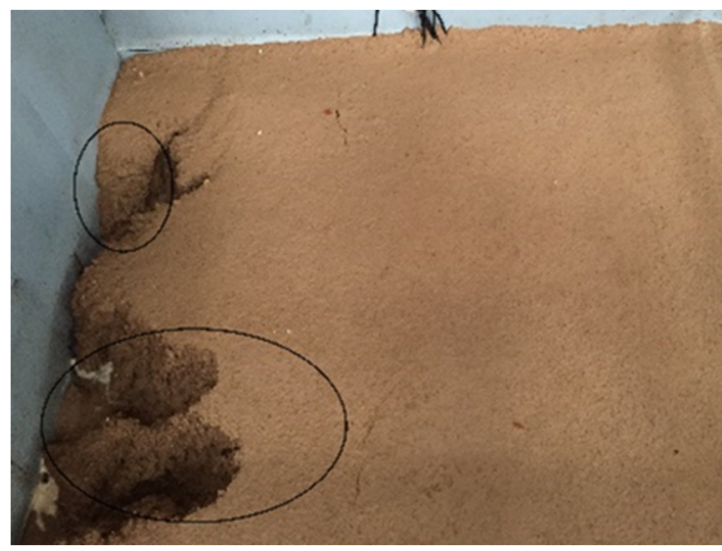

Figure 10. Collapsible deformation on the posterior wall.

The downward movement of the wet front was similar to the results reported by Tian et al. [55], but the downward movement rate of the wet front was larger than that recorded by them, because the terraced ridges have the capacity to store water, and the accumulated water increases the water infiltration gradient and accelerates the rate of water downward movement. This also proves that the measures of slope conversion can effectively intercept rainfall, and the benefits of water and sediment reduction are obvious in the Loess Plateau. This is also supported by the research results of Bai et al. [56].

\subsubsection{Water Content}

In accordance with the monitored data from the slope moisture sensor, the change in slope moisture content in the whole process can be understood. Figure 11a shows that the moisture content of each soil layer at different depths of slope varied with rainfall duration 
and post-rain duration. Within $0.5 \mathrm{~h}$ of the beginning of rainfall, the moisture content of layers $\mathrm{A}, \mathrm{B}$, and $\mathrm{C}$ of the slope increased to $0.83 \% / \mathrm{h}$, and the change was obvious, while the moisture content of soil in layers D, E, and F changed very little, due to the infiltration of rainwater going from shallow to deep. With the increase in rainfall time, rainwater infiltrated and the moisture content of the whole slope increased continuously. The increased rate of moisture content of the upper soil was about $2 \sim 2.83 \% / \mathrm{h}$, which is higher than the previous value of $0.83 \% / \mathrm{h}$, due to the continuous increase in soil moisture content, the decrease in matrix suction, and the increase in the permeability coefficient. For $\mathrm{D}, \mathrm{E}$, and $\mathrm{F}$, there is an obvious break point in the curve, and the moisture content suddenly increased at about 4:00 p.m., which indicated that there were violent activities in the soil; deep cracks appeared in the soil, the soil began to lose stability and the sliding surface formed. Thus, the change in moisture content strongly influenced soil failure. First, the increase in moisture content led to an increase in pore water pressure and a decrease in effective stress, thus resulting in a decrease in soil shear strength; second, the increase in moisture content increased the permeability of the water, which led to a decrease in side slope stability. The dual effect of rainfall infiltration leading to water content variation may be an important reason for the side slope's rainfall-induced instability. Figure $11 \mathrm{~b}$ shows that the moisture content at the top of the slope rose the fastest and had the largest change range. At around 1:00 p.m. on 11 November, due to the shallow landslides of the slope body, the moisture content of the slope rapidly dropped to $0 \%$, followed by the toe of the slope, with the smallest change and the smallest range in the middle of the slope.

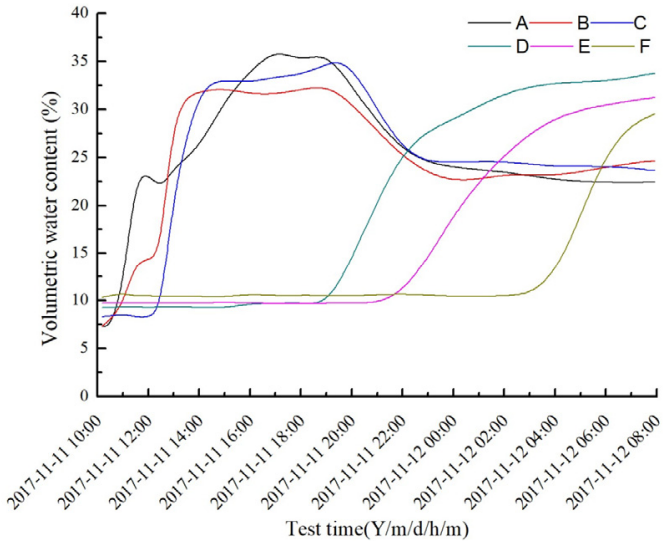

(a)

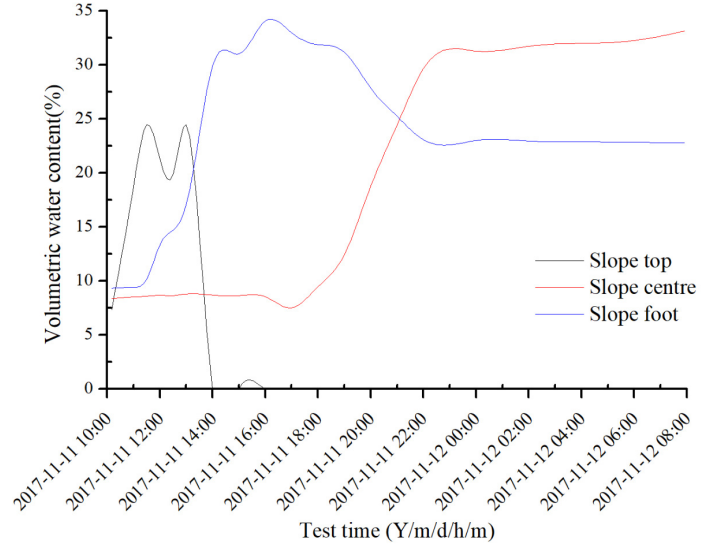

(b)

Figure 11. Variation of volumetric water content of soil layers and feature points with time; (a) The moisture content of each soil layer at different depths of slope varied with rainfall duration, (b) The moisture content at the top, center, and foot of the slope.

\subsubsection{Pore Water Pressure and Suction}

Figure 12 shows the variation in pore water pressure and suction with rainfall. Figure 12a shows that the pore water pressure first increased and then tended to be stable with the rainfall duration. The variation in pore water pressure at the top of the slope ranged most before the shallow landslides of the slope, and the maximum value was $2.4 \mathrm{kPa}$. Since the sensor was exposed outside the slope after shallow landslides, it rapidly dropped to $0 \mathrm{kPa}$. The change in pore water pressure at the measuring point at the toe of slope was slightly later than that at the top of slope, with a maximum value of $3.6 \mathrm{kPa}$. At the end of the rainfall event, the pore water pressure gradually decreased and finally tended to be stable around $2.5 \mathrm{kPa}$. The change in pore water pressure at the measuring point in the middle of the slope changed later than at the measuring points at the top and toe of the slope, with the water infiltration reaching the measuring point at around 4:00 p.m., then increasing gradually, and finally tending to be about $2.8 \mathrm{kPa}$. As Figure $12 \mathrm{~b}$ 
shows, the suction (negative pore water pressure) varied from 7.4 to $14.6 \mathrm{kPa}$, showing a sharp decrease at first and then a stable trend. The reason for this finding is that with rainfall infiltration, the moisture content of each measuring point increased, and the suction decreased sharply. After the rainfall, the moisture content of each measuring point decreased slowly due to evaporation, so the suction increased slowly and finally tended to be stable. Notably, the Campbell 257 soil suction sensor uses an indirect-method suction sensor (with a measuring range of $200 \mathrm{kPa}$ ), but the air intake value of soil material is small, so when the suction of the soil sample is lower than $10 \mathrm{kPa}$, the measurement accuracy of the sensor is poor.

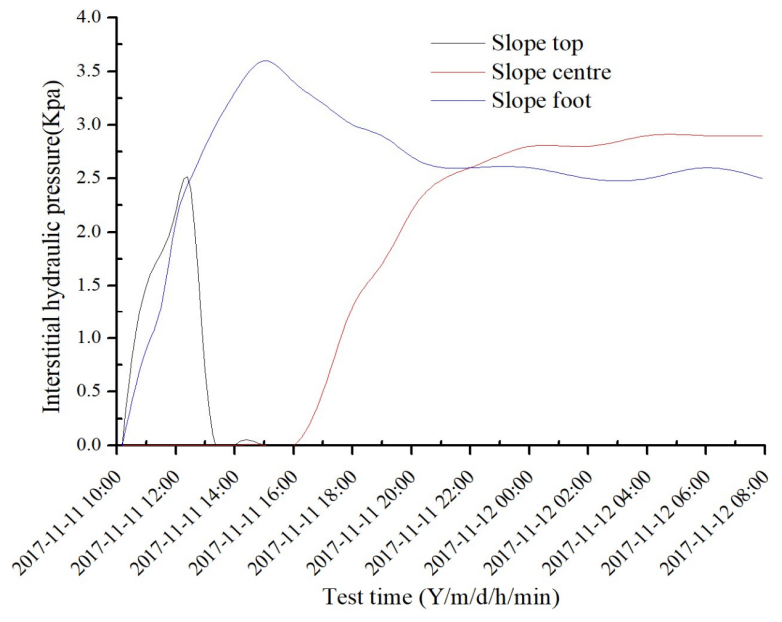

(a)

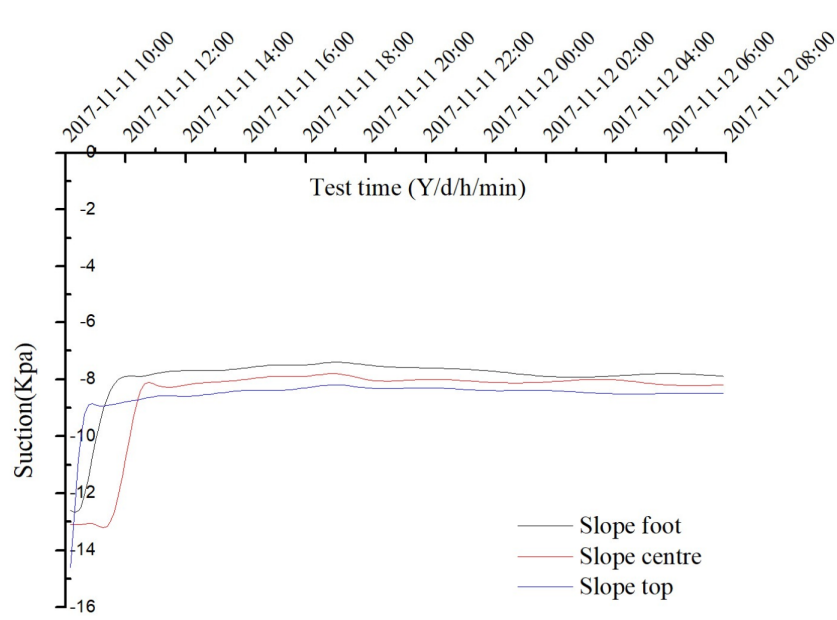

(b)

Figure 12. Variation of pore water pressure and soil water suction of feature points with time; (a) Variation of pore water pressure at top, center, and foot of slope, (b) soil water suction at top, center, and foot of slope.

\subsection{Shape Characteristics and Mechanism of Deep Slip Surface \\ 3.3.1. Shape Characteristics}

The displacement of measuring points near the top of slope (A1, A2, A3, A4, and A5) was $0.5-40 \mathrm{~mm}$ and the direction was $40-50^{\circ}$ to the horizontal; the displacement of measuring points near the slope surface (B5, C6, and D6) was 2.5-15.6 mm and the direction was $60-70^{\circ}$ to the horizontal; the displacement of measuring points (E7 and F7) near the slope toe was $1.2-6.0 \mathrm{~mm}$ and the direction was $80-85^{\circ}$ to the horizontal. The displacement of the deepest measuring points (C1, D1, D2, E1, E2, E3, F1, F2, F3, F4, and F5) was almost $0 \mathrm{~mm}$. Through analysis of the above measurements, we found that the movement of the soil near the slope was the most intense; the displacement was the largest here, as was the displacement change rate, as it was the main active area of soil. With increasing depth of the measuring points, the displacement of the soil became increasingly small. When the depth reached the deepest points, there was no displacement. With the increase in depth, the angle between the displacement of each measuring point and the horizontal direction was increasingly large, and some points were close to $90^{\circ}$. This shows that both horizontal and vertical movements occurred in the soil landslides, but with the increase in depth, the horizontal movement transformed into vertical movement, and finally, at a certain depth, the soil movement was close to vertical movement. The approximate depth of the deep slip surface can be determined from the tracer point with no displacement. If the displacement of $\mathrm{B} 1, \mathrm{D} 2$, and $\mathrm{F} 5$ points is $0 \mathrm{~mm}$, the depth of the deep slip surface is approximately 0.35 , 0.75 , and $1.15 \mathrm{~m}$, respectively. Combining the depth of the deep slip surface obtained by each tracing point moving to $0 \mathrm{~mm}$ and the staggered fracture at the trailing edge of the landslide, the position of the deep slip surface can be determined; the slip surface radius was $1.43 \mathrm{~m}$. The shape of the deep slip surface is shown in Figure 13. 


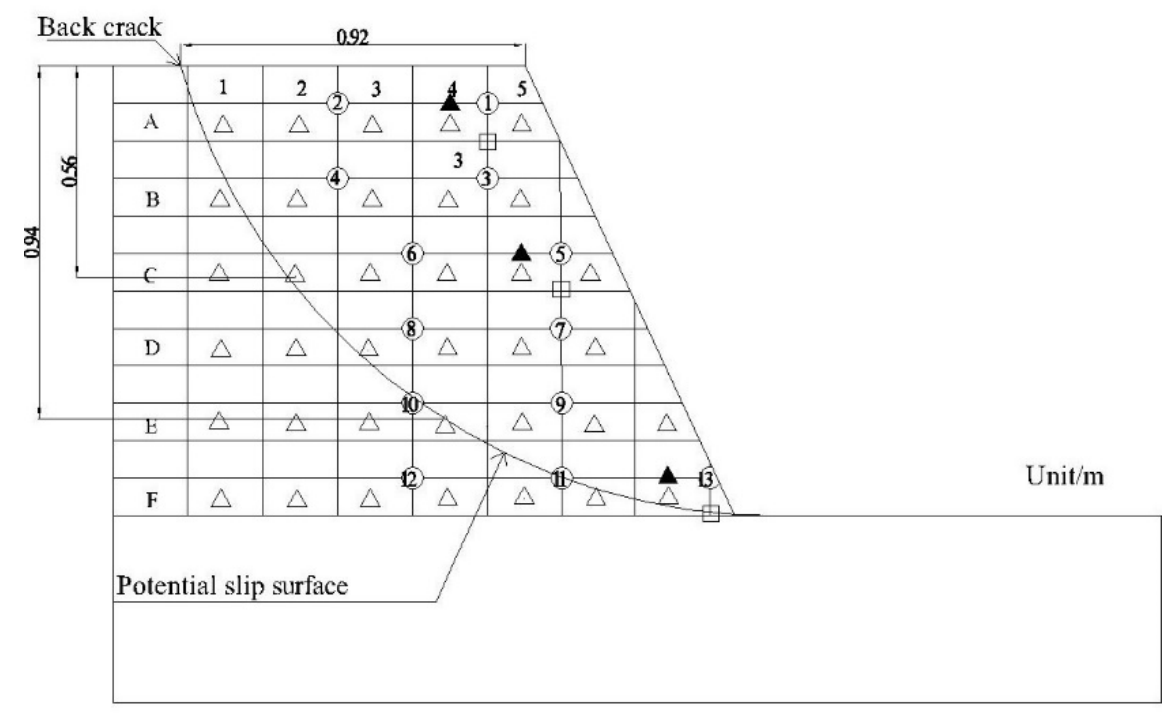

Figure 13. The deep shape of sliding surface. Different letters indicate soil layers; Numbers indicate soil columns; $\bigcirc$ indicates soil water content sensor; $\square$ indicates pore water pressure sensor; $\triangle$ indicates monitor point of displacement; $\boldsymbol{\Lambda}$ indicates soil water suction sensor.

Rainfall is an important factor that causes landslides in terraces, it increases the sliding moment and reduces the anti-skid moment, finally forming a slip surface similar to a circular arc. This is similar to the results of studies by Zhang et al. [36] and Liu et al. [38]. However, the abovementioned studies used numerical simulation methods to study terraced landslides, which are less convincing. Our test explains the mechanism and process of terraced landslides and fully verifies the accuracy of the above-mentioned studies. However, this test only studied a single terrace, and we did not consider landslides on multi-level terraces, which will be the focus and direction of future research. Wu et al. [57] studied the causes of landslides in terraced fields in the loess area caused by over-irrigation, and the landslides at the Heifangtai can be classified into two different types based on their composition: loess landslides and loess-bedrock landslides, characterized by highspeed, long-distance sliding and low-speed, short-distance sliding respectively. Agnoletti et al. [58], taking terraced fields as the research object, explained that the terraced field can better reduce the possibility of shallow landslide disasters relative to slope field, and have less impact on deep landslides under extreme rainfall conditions. This is also consistent with the results of our experimental study, highlighting the guiding significance of this study for terraced landslides in the whole loess hilly and gully area.

\subsubsection{Mechanical Mechanism}

To study the mechanism and process of deep sliding surfaces in terraces under extreme rainfall, the safety factor of sliding surfaces in terraces was calculated using the Swedish slice method. This method divides the soil above the slip surface into several strips to analyze the force and moment equilibrium on each strip, and to obtain the safety factor of soil stability under the limit equilibrium state [59]. In this experiment, the soil strips above the sliding surface are divided into seven vertical strips according to the location of the sensors. Before solving the safety factor, the following assumptions are made: (i) the force between the strips has little effect on the overall stability, which can be ignored; (ii) the moisture content of each soil strip is the average value of all moisture content sensors on the soil strip; (iii) the cohesive force and internal friction angle of each soil block are used form [60], namely, $c_{i}=\alpha w_{i}^{-\beta}$. As shown in Figure 14, according to the equilibrium condition of radial force

$$
N_{i}=W_{i} \cos \alpha_{i}
$$




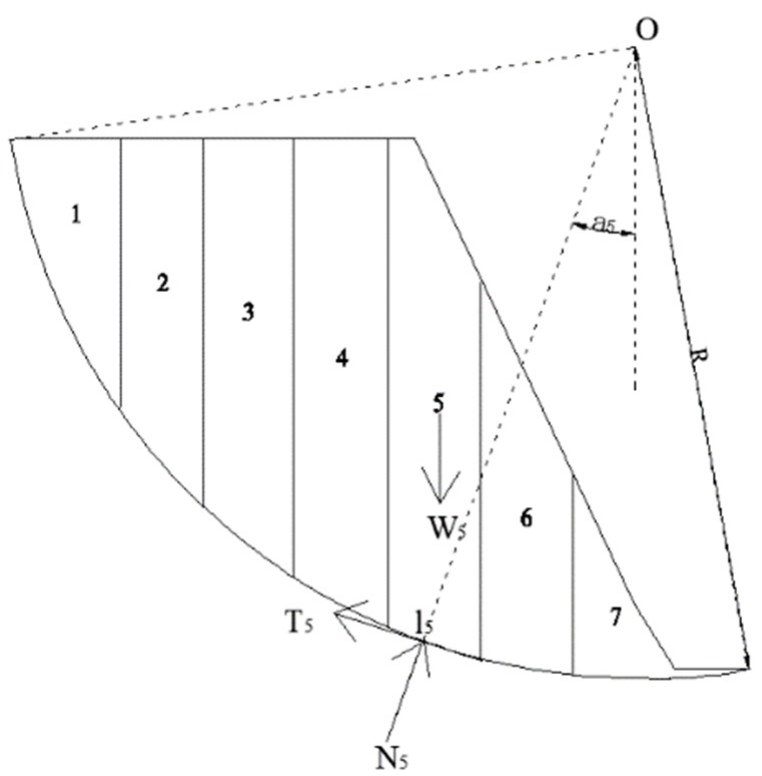

Figure 14. Analysis of the forces of the Swedish slice method.

According to the limit equilibrium condition on the arc surface,

$$
T_{i}=\frac{c_{i} l_{i}+N_{i} \tan \varphi_{i}}{F_{S}}
$$

The anti-sliding moment generated on the sliding surface is,

$$
\sum T_{i} R=\sum \frac{c_{i} l_{i}+N_{i} \tan \varphi_{i}}{F_{S}} \times R
$$

From the moment balance, we can finally obtain

$$
F_{\mathcal{S}}=\frac{\sum \alpha w_{i}^{-\beta} l_{i}+W_{i} \cos \alpha_{i} \tan \varphi_{i}}{\sum W_{i} \sin \alpha_{i}}
$$

here $\alpha_{i}$ is the bottom slope angle of the strip $i ; W_{i}$ is the sum of the self-weight of strip $i$ and the upper load; $N_{i}$ is the total normal force at the bottom of strip $i ; T_{i}$ is the total tangential resistance of strip $i$ at the bottom; $F_{S}$ is the safety factor of the sliding arc; $c_{i}$ is the cohesion of block $i ; l_{i}$ is the bottom length of the block $i ; \varphi_{i}$ is the internal friction angle of block $i$; $R$ is the arc radius of the sliding surface; $w_{i}$ is the soil water content, $(\times 100) \alpha$ and $\beta$ can be obtained by linear interpolation in Tables 2 and 3.

Table 2. Selection of cohesion parameters of unsaturated loess [61].

\begin{tabular}{ccc}
\hline Soil Dry Density $\left(\mathrm{g} / \mathrm{cm}^{-3}\right)$ & $\alpha$ & $\beta$ \\
\hline 1.2 & 37.67 & 1.602 \\
1.3 & 42.3 & 1.615 \\
1.4 & 79.33 & 1.782 \\
1.5 & 108.901 & 1.795 \\
1.6 & 56.687 & 1.503 \\
\hline
\end{tabular}


Table 3. Selection of internal friction angle of unsaturated loess [61].

\begin{tabular}{|c|c|c|c|c|c|c|}
\hline \multicolumn{2}{|c|}{ Soil Dry Density $\left(\mathrm{g} / \mathrm{cm}^{-3}\right)$} & \multirow{2}{*}{$\begin{array}{c}\mathbf{1 . 2} \\
20.8\end{array}$} & \multirow{2}{*}{$\begin{array}{c}1.3 \\
21\end{array}$} & \multirow{2}{*}{$\begin{array}{c}\mathbf{1 . 4} \\
21.1\end{array}$} & \multirow{2}{*}{$\begin{array}{c}\mathbf{1 . 5} \\
21.6\end{array}$} & \multirow{2}{*}{$\begin{array}{c}\mathbf{1 . 6} \\
22.6\end{array}$} \\
\hline \multirow{14}{*}{ soil water content } & $7 \%$ & & & & & \\
\hline & $9 \%$ & 20.4 & 20.7 & 20.9 & 21.5 & 22.5 \\
\hline & $11 \%$ & 20.1 & 20.3 & 20.7 & 21.3 & 22.3 \\
\hline & $13 \%$ & 19.8 & 20 & 20.5 & 21.2 & 22.1 \\
\hline & $15 \%$ & 19.6 & 19.6 & 20.3 & 20.9 & 21.9 \\
\hline & $17 \%$ & 19.3 & 19.4 & 20.1 & 20.8 & 21.6 \\
\hline & $19 \%$ & 18.9 & 19.2 & 19.9 & 20.8 & 21.4 \\
\hline & $21 \%$ & 18.6 & 19 & 19.7 & 20.5 & 21.2 \\
\hline & $23 \%$ & 18.2 & 18.8 & 19.5 & 20.4 & 21.1 \\
\hline & $25 \%$ & 17.9 & 18.6 & 19.3 & 20.2 & 21 \\
\hline & $27 \%$ & 17.6 & 18.4 & 19.1 & 20.2 & 20.9 \\
\hline & $29 \%$ & 17.2 & 18.2 & 18.9 & 20 & 20.8 \\
\hline & $31 \%$ & 16.8 & 18 & 18.7 & 19.9 & 20.6 \\
\hline & $33 \%$ & 16.5 & 17.8 & 18.5 & 19.8 & 20.5 \\
\hline
\end{tabular}

Figure 15 shows the variation law of terraces' safety factor with test time. The safety factor first decreased, then increased, and finally slowly increased and tended to be stable. From 10:00 a.m. to 3:00 p.m., with the continuous infiltration of rainfall, the self-weight of the upper soil on the sliding surface increased, which increased the sliding torque. The decrease in cohesion led to the decrease in anti-sliding torque, which was the reason for the decrease in the safety factor. From 3:00 p.m. to 4:00 p.m., due to the sliding torque being greater than the anti-sliding torque, the sliding surface gradually formed, and the time of deep sliding surface began to form earlier than the terraced shallow landslides; 4:00 p.m. to 5:00 p.m., due to the terraces forming a new stable state; the slope was slowed down and the safety factor was larger than the initial stage. From 5:00 p.m. to 9:00 p.m., the change law was similar to that of the initial rainfall, which also showed that rainfall infiltration was the dominant factor leading to safety factor; after 9:00 p.m., the safety factor increased slowly and tended to be stable, because after the rainfall, the soil inside the terraces slowly dried and evaporated naturally, so that the soil moisture content decreased slowly and tended to be stable. The mechanical mechanism of deep slip surfaces in terraces was that through the sliding moment of the sliding body being greater than the anti-sliding moment. The formation of a deep sliding surface in a terraced slope was mainly the result of the interaction of hydraulic erosion and gravity erosion, due to rainfall infiltration, soil moisture content increase, pore water pressure increase, and suction decrease. It increased the bulk density of the sliding body, thereby increasing the sliding torque; however, rainfall infiltration reducing the cohesion and internal friction angle of the sliding body, thereby reduced the anti-sliding torque. With the continuous rainfall, the anti-sliding torque was equal to the sliding torque at a certain time, and the terraced slope was in the limit equilibrium state. The sliding surface began to develop and form from this moment, and the development of the erosion gully accelerated the formation process of the sliding surface. In this study, the rainfall threshold for deep landslides in terraces was $500 \mathrm{~mm}$, which is similar to the results of Zhuang et al. [3], and provides data support for landslides in loess hilly and gully areas.

\subsubsection{Variation in Characteristic Points Displacement with Accumulated Rainfall}

Figure 16 shows the relation curve between the displacement of three characteristic monitoring points (A5, C6, and F7) and the accumulated rainfall. With the increase in accumulated rainfall, the soil displacement gradually increased, with the largest displacement occurring at the top of the slope, the second largest at the slope center, and the smallest at the foot of the slope. At around 2:00 p.m. on 11 November, the displacement increased sharply. After the collapse, the displacement increased slowly and remained unchanged at 8:00 a.m. on 12 November. The displacements of the top, center and foot of the slope were $40.3 \mathrm{~mm}, 15.6 \mathrm{~mm}$, and $6.0 \mathrm{~mm}$, respectively. 


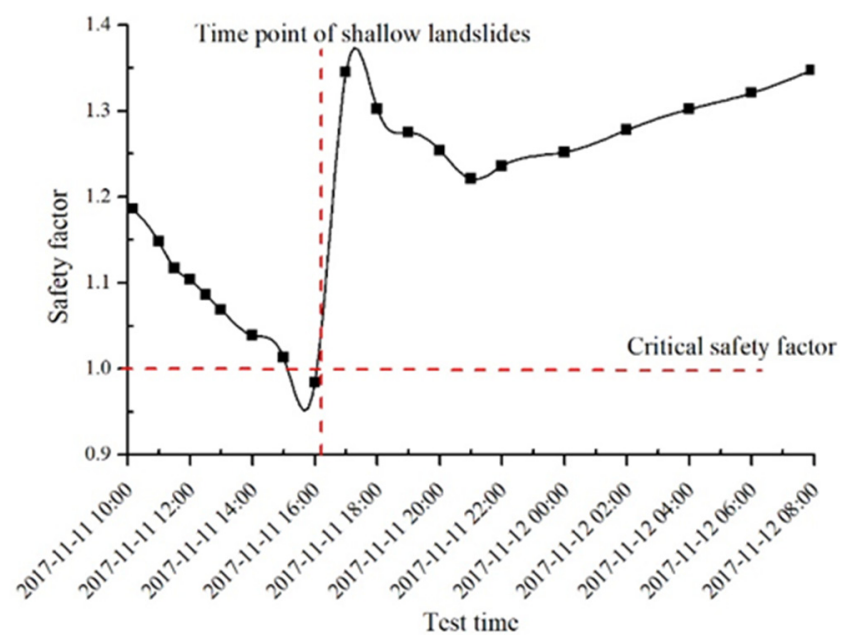

Figure 15. The changes of safety factor of terraces with test time.

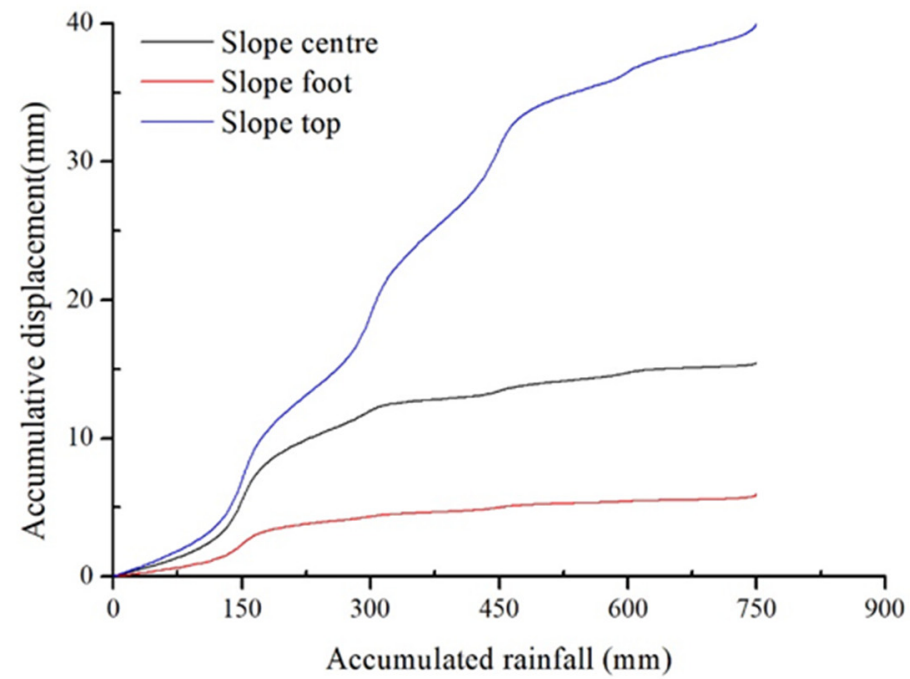

Figure 16. Displacement of characteristic points and its comparison with accumulative rainfall.

The variation law of the slope top, the middle of the slope, and the characteristic points of the slope foot was similar to that reported by Chen et al. [62], but the displacement was generally larger than the above research because of the high rainfall intensity and the long rainfall duration. In future studies, we must examine the impact of different rainfall intensities and total rainfall on terraced landslides.

\section{Summary and Conclusions}

In this paper, where we selected newly built bare-land terraces as the research object, the laboratory model test method was used to study the mechanism and process of shallow landslides and deep slip surface in terraces under extreme rainfall conditions. The main conclusions were as follows.

Shallow landslides in terraces are formed under the interaction of water erosion and gravity erosion, and the main driving force is from headward erosion and rill erosion. The superficial-layer shallow landslides of the terraces under the action of extreme rainfall can be divided into six stages. The width of the erosion ditch on the terraced slope was $17.8 \mathrm{~cm}$ and the volume of shallow landslides in terraces was $0.24 \mathrm{~m}^{3}$.

The mechanism of the slip surface in the terraces is rainfall infiltration, which increases the water content of the soil, increases the pore water pressure, and decreases the suction force, which leads to the anti-slip torque being less than the sliding torque, causing a slip 
surface to appear inside the terrace. Under extreme rainfall conditions, terraces formed a circular sliding surface with a radius of $1.43 \mathrm{~m}$ and an angle of $92^{\circ}$. The appearance of this slip surface was earlier than the appearance of shallow landslides in terraces, and rill erosion accelerated the formation of deep slip surfaces. The threshold of rainfall that caused deep landslides in terraces was $500 \mathrm{~mm}$.

Author Contributions: P.G. and X.M. conceived and designed the research theme. Y.W. and P.G. collected the data and designed methods. Y.W. analyzed the data and interpreted the results. Y.W. and P.G. wrote and edited the paper. M.L.; Y.S.; H.W. processed the images and forms. All authors have read and agreed to the published version of the manuscript.

Funding: This research was funded by the National Key Scientific Research Project (Grant No. 2016YFC0501707).

Institutional Review Board Statement: Not applicable.

Informed Consent Statement: Not applicable.

Data Availability Statement: Data was contained within the article.

Acknowledgments: We thank the editors of the journal and the reviewers for their useful comments and suggestions to improve the paper quality greatly. Special thanks to Guangju Zhao and Wenyi Sun from Northwest A\&F University, State Key Lab Soil Eros \& Dryland Farming Loess P, China and Chinese Acad Sci \& Minist Water Resources, Inst Soil \& Water Conservat provided valuable feedback on an earlier version of this manuscript.

Conflicts of Interest: The authors declare no conflict of interest.

\section{References}

1. Wei, W.; Chen, D.; Wang, L.; Daryanto, S.; Li, J.; Yu, Y.; Lu, Y.; Sun, G.; Feng, T. Global synthesis of the classifications, distributions, benefits and issues of terracing. Earth Sci. Rev. 2016, 159, 388-403. [CrossRef]

2. Li, Y.; Lindstrom, M.J. Evaluating Soil Quality-Soil Redistribution Relationship on Terraces and Steep Hillslope. Soil Sci. Soc. Am. J. 2001, 65, 1500-1508. [CrossRef]

3. Zhuang, J.; Peng, J.; Wang, G.; Iqbal, J.; Wang, Y.; Li, W.; Xu, Q.; Zhu, X. Prediction of rainfall-induced shallow landslides in the Loess Plateau, Yan'an, China, using the TRIGRS model. Earth Surf. Process. Landf. 2017, 42, 915-927. [CrossRef]

4. Van Dijk, A.I.J.M.; Bruijnzeel, L.A. Runoff and soil loss from bench terraces. 1. An event-based model of rainfall infiltration and surface runoff. Eur. J. Soil Sci. 2004, 55, 299-316. [CrossRef]

5. Fan, J.; Wang, Q.J.; Scott, B.J. Soil water depletion and recharge under different land cover in China's Loess Plateau. Ecohydrology 2015, 9, 396-406. [CrossRef]

6. Dijk, A.I.J.M.; Bruijnzeel, L.A. Terrace erosion and sediment transport model: A new tool for soil conservation planning in bench-terraced steep lands. Software 2003, 18, 839-850.

7. Rodrigo-Comino, J.; Seeger, M.; Iserloh, T.; González, J.M.S.; Ruiz-Sinoga, J.D.; Ries, J.B. Rainfall-simulated quantification of initial soil erosion processes in sloping and poorly maintained terraced vineyards-Key issues for sustainable management systems. Sci. Total Environ. 2019, 660, 1047-1057. [CrossRef] [PubMed]

8. Wen, Y.F.; Gao, P.; Mu, X.M. Response of soil erosion to rainfall intensity in terraced slope in the Loess Plateau. J. Sediment Res. 2017, 6, 46-51. (In Chinese)

9. Shi, Q.; Wang, W.; Guo, M.; Chen, Z.; Feng, L.; Zhao, M.; Xiao, H. The impact of flow discharge on the hydraulic characteristics of headcut erosion processes in the gully region of the Loess Plateau. Hydrol. Process. 2020, 34, 718-729. [CrossRef]

10. Tony, L.T.; Zhan, G.W.; Jia, Y.M. An analytical solution for rainfall infiltration into an unsaturated infinite slope and its application to slope stability analysis. Int. J. Numer. Anal. Methods Geomech. 2012, 37, 1737-1760.

11. Jiao, J.Y.; Wang, W.Z. Quality and soil-water conservation effectiveness of level terrace on the Loess Plateau. Trans. CSAE 1999, 2, 59-63. (In Chinese)

12. Bandara, S.; Ferrari, A.; Laloui, L. Modelling landslides in unsaturated slopes sub-jected to rainfall infiltration using ma-terial point method. Int. J. Numer. Anal. Methods Geomech. 2016, 40, 1358-1380. [CrossRef]

13. Ma, K.-C.; Tan, Y.-C.; Chen, C.-H. The influence of water retention curve hysteresis on the stability of unsaturated soil slopes. Hydrol. Process. 2011, 25, 3563-3574. [CrossRef]

14. Wang, J.D.; Gu, T.F.; Zhang, M.S. Experimental study of loess disintegration charac-teristics. Earth Surf. Process. Landf. 2019, 44, 1317-1329. [CrossRef]

15. Garcia, E.; Oka, F.; Kimoto, S. Numerical analysis of a one-dimensional infiltration problem in unsaturated soil by a seepagedeformation coupled method. Int. J. Numer. Anal. Methods Geomech. 2011, 35, 544-568. [CrossRef] 
16. Ivanov, V.I.; Arosio, D.; Tresoldi, G.; Hojat, A.; Zanzi, L.; Papini, M.; Longoni, L. Investigation on the Role of Water for the Stability of Shallow Landslides-Insights from Experimental Tests. Water 2020, 12, 1203. [CrossRef]

17. Bui, D.T.; Pradhan, B.; Lofman, O.; Revhaug, I.; Dick, Ø.B. Regional prediction of landslide hazard using probability analysis of intense rainfall in the Hoa Binh province, Vietnam. Nat. Hazards 2012, 66, 707-730. [CrossRef]

18. Vonstorch, H.; Zorita, E.; Cubasch, U. Downscaling of global cli-mate-change estimates to regional scales-An application to iberian rainfall in wintertime. J. Clim. 1993, 6, 1161-1171. [CrossRef]

19. Lin, H.Z.; Yu, Y.Z.; Li, G.X. Influence of rainfall characteristics on soil slope failure. J. Rock Mech. Eng. 2009, 1, 198-294. (In Chinese)

20. Zuo, Z.B.; Zhang, L.L.; Wang, J.H. Model tests on rainfall-induced colluvium land-slides: Effects of particle-size distribution. J. Geotech. Eng. 2015, 7, 1319-1327. (In Chinese)

21. Li, H.Q.; Sun, H.Y.; Sun, X.M. Influence of rainfall infiltration on slopes by physical model test. J. Geotech. Eng. 2009, 3,589-594. (In Chinese)

22. Jeong, S.; Lee, K.; Kim, J.; Kim, Y. Analysis of Rainfall-Induced Landslide on Unsaturated Soil Slopes. Sustainability 2017, 9, 1280. [CrossRef]

23. Aleotti, P. A warning system for rainfall-induced shallow failures. Eng. Geol. 2004, 73, 247-265. [CrossRef]

24. Xu, G.M.; Wang, G.L.; Gu, X.W. Centrifuge modeling for instability of excavated slope inexpansive soil due to water in-filtration. J. Geotech. Eng. 2006, 2, 270-273. (In Chinese)

25. Wang, G.; Sassa, K. Factors affecting rainfall-induced flowslides in laboratory flume tests. Géotechnique 2001, 7, 587-599. [CrossRef]

26. Tohari, A.; Nishigaki, M.; Komatsu, M. Laboratory Rainfall-Induced Slope Failure with Moisture Content Measurement. J. Geotech. Geoenvironmental Eng. 2007, 133, 575-587. [CrossRef]

27. Huang, C.-C.; Lo, C.-L.; Jang, J.-S.; Hwu, L.-K. Internal soil moisture response to rainfall-induced slope failures and debris discharge. Eng. Geol. 2008, 101, 134-145. [CrossRef]

28. Yilmaz, I.; Karacan, E. A Landslide in Clayey Soils: An Example from the Kızıldag Region of the Sivas-Erzincan Highway (Sivas-Turkey). Environ. Geosci. 2008, 9, 35-42. [CrossRef]

29. Benn, J.L. Landslide events on the West Coast, South Island, 1867-2002. N. Z. Geogr. 2005, 61, 3-13. [CrossRef]

30. Yang, Q.; Zhao, Z.; Benoy, G.; Chow, T.L.; Rees, H.W.; Bourque, C.P.-A.; Meng, F.-R. A Watershed-scale Assessment of CostEffectiveness of Sediment Abatement with Flow Diversion Terraces. J. Environ. Qual. 2010, 39, 220-227. [CrossRef]

31. Li, X.H.; Yang, J.; Zhao, C.Y. Runoff and sediment from orchard terraces in southeastern china. Land Degrad. Dev. 2012, 25, 184-192. [CrossRef]

32. Li, H.J.; Gao, J.E.; Zhang, Y.X. Analysis of Yan'an extreme rainfall characteristics and impacts of erosion disasters on terraces. J. Soil Water Conserv. 2016, 6, 79-84. (In Chinese)

33. Stavi, I.; Rozenberg, T.; Al Ashhab, A.; Argaman, E.; Groner, E. Failure and Collapse of Ancient Agricultural Stone Terraces: On-Site Effects on Soil and Vegetation. Water 2018, 10, 1400. [CrossRef]

34. Jiang, D.S. The design of the cross-sections of terrace in the loess plateau of china. J. Soil Water Conserv. 1987, 02, 28-36. (In Chinese)

35. Ge, Y.Q. Analysis of the stability of terrace soil edge in sandy mountains. Soil Water Conserv. 1999, 7, 32-33. (In Chinese)

36. Zhang, J.; Han, T.C.; Dou, H.Q.; Ma, S.G. Research on slope stability of terrace based on crop irrigation infiltration. J. Sichuan Univ. 2014, S1, 79-85. (In Chinese)

37. Yang, J.; Li, G.L.; Wei, Z. Teat on expansion ratio and mechanical property of terrace soil ridges of southern shaanxi. Soil Water Conserv. 2015, 5, 40-43. (In Chinese)

38. Liu, J.L.; Tian, J.; Zheng, T.T. Optimized design of loess terrace based on slope stability. Sci. Soil Water Conserv. 2020, 4, 21-28. (In Chinese)

39. Derbyshire, E. Geological hazards in loess terrain, with particular reference to the loess regions of China. Earth Sci. Rev. 2001, 1-3, 253-266. [CrossRef]

40. Chen, J.; Wang, Y.j.; Chen, Y. Rb and Sr Geochemical Characterization of the Chinese Loess Stratigraphy and Its Implications for Palaeomonsoon Climate. Acta Geol. Sin. Engl. Ed. 2010, 74, 279-288.

41. Zheng, F.-L.; Huang, C.-H.; Norton, L.D. Vertical Hydraulic Gradient and Run-On Water and Sediment Effects on Erosion Processes and Sediment Regimes. Soil Sci. Soc. Am. J. 2000, 64, 4-11. [CrossRef]

42. Li, X.; Wang, L.; Hong, B.; Li, L.; Liu, J.; Lei, H. Erosion characteristics of loess tunnels on the Loess Plateau: A field investigation and experimental study. Earth Surf. Process. Landf. 2020, 45, 1945-1958. [CrossRef]

43. Wu, H.; Xu, X.; Zheng, F.; Qin, C.; He, X. Gully morphological characteristics in the loess hilly-gully region based on 3D laser scanning technique. Earth Surf. Process. Landf. 2018, 43, 1701-1710. [CrossRef]

44. Shen, N.; Wang, Z.-L.; Zhang, Q.; Wu, B.; Liu, J.; Nan, S. Modelling the process of soil detachment by rill flow on steep loessial hillslopes. Earth Surf. Process. Landf. 2020, 45, 1240-1247. [CrossRef]

45. Han, P.; Ni, J.R.; Li, T.H. Headcut and bank landslip in rill evolution. J. Basic Sci. Eng. 2002, 2, 115-125. (In Chinese)

46. Acharya, G.; Cochrane, T.A. Rainfall induced shallow landslides on sandy soil and impacts on sediment discharge: A flume based investigation. In Proceedings of the 12th Conference of International Association for Computer Methods and Advances in Geomechanics, Goa, India, 1-6 October 2008.

47. Zhong, Q.M.; Chen, S.S.; Mei, S.A. Breach Mechanism and Breach Process Simulation of Homogeneous Cohesive Earthen Dam Due to Overtopping. Adv. Eng. Sci. 2019, 51, 25-32. (In Chinese) 
48. Morris, M.W.; Hassan, M.A.A.M.; Vaskinn, K.A. Breach formation: Field test and la-boratory experiments. J. Hydraul. Res. 2007, 45, 9-17. [CrossRef]

49. Hanson, G.J.; Cook, K.R.; Hunt, S.L. Physical modeling of overtopping erosion and breach formation of cohesive embankments. Trans. ASAE 2005, 48, 1783-1794. [CrossRef]

50. Sun, P.; Wang, G.; Wu, L.Z. Physical model experiments for shallow failure in rain-fall-triggered loess slope, Northwest China. Bull. Eng. Geol. Environ. 2019, 78, 4363-4382. [CrossRef]

51. Yuan, J.P.; Lei, T.W.; Guo, S.Y. Study on spatial variation of infiltration rates for small watershed in loess plateau. J. Hydraul. Eng. 2001, 10, 88-92. (In Chinese)

52. Liu, X.Y.; Wang, F.G.; Yang, S.T. Study on harmony equilibrium between water re-sources and economic society development. J. Hydraul. Eng. 2014, 45, 793-800. (In Chinese)

53. Huang, J.; Wu, P.; Zhao, X. Effects of rainfall intensity, underlying surface and slope gradient on soil infiltration under simulated rainfall experiments. Catena 2013, 104, 93-102. [CrossRef]

54. Cui, G.; Zhu, J. Infiltration Model Based on Traveling Characteristics of Wetting Front. Soil Sci. Soc. Am. J. 2018, 82, 45-55. [CrossRef]

55. Tian, S. Indoor Model Test Study on Fill Slope under Earthquake and Rainfull. Pearl River 2019, 40, 61-70. (In Chinese)

56. Bai, J.; Yang, S.; Zhang, Y.; Liu, X.; Guan, Y. Assessing the Impact of Terraces and Vegetation on Runoff and Sediment Routing Using the Time-Area Method in the Chinese Loess Plateau. Water 2019, 11, 803. [CrossRef]

57. Wu, W.J.; Su, X.; Meng, X.M. Characteristics and Origin of Loess Landslides on Loess Terraces at Heifangtai, Gansu Province, China. Appl. Mech. Mater. 2014, 694, 455-461. [CrossRef]

58. Agnoletti, M.; Errico, A.; Santoro, A.; Dani, A.; Preti, F. Terraced Landscapes and Hydrogeological Risk. Effects of Land Abandonment in Cinque Terre (Italy) during Severe Rainfall Events. Sustainability 2019, 11, 235. [CrossRef]

59. Baker, R. Determination of the critical slip surface in slope stability computations. Int. J. Numer. Anal. Methods Geomech. 1980, 4, 333-359. [CrossRef]

60. Dang, J.Q.; Li, J. The Influence of Water Content on the Strength of Unsaturated Loess. J. Northwest Agric. Univ. 1996, 1, 57-60.

61. Dang, J.Q.; Li, J. The structural strength and shear strength of unsaturated loess. Shuili Xuebo 2001, 7, 0079-05. (In Chinese)

62. Chen, W.; Luo, Y.S.; Wu, C.P. The Laboratory Model Test Sdudy of Loess Slope uder the Artificial Rainfall. China Rural Water Hydropower 2013, 5, 100-104. (In Chinese) 